\title{
Promoter-Specific Effects of DREADD Modulation on Hippocampal Synaptic Plasticity and Memory Formation
}

\author{
Alberto J. López, ${ }^{1,2,3}$ Enikö Kramár, ${ }^{1,2,3}$ CDina P. Matheos, ${ }^{1,2,3}$ André 0. White, , ${ }^{1,2,3}$ Janine Kwapis, ${ }^{1,2,3}$ \\ Annie Vogel-Ciernia, ${ }^{4}{ }^{-}$Keith Sakata, ${ }^{1,2,3}$ Monica Espinoza, ${ }^{1,2,3}$ and Marcelo A. Wood ${ }^{1,2,3}$ \\ ${ }^{1}$ Department of Neurobiology and Behavior and ${ }^{2}$ Center for the Neurobiology of Learning and Memory, University of California, Irvine, Irvine, California \\ 92697, ${ }^{3}$ UC Irvine Center for Addiction Neuroscience, and ${ }^{4}$ Davis M.I.N.D. Institute, University of California, Davis, Davis, California 96516
}

Designer receptors exclusively activated by designer drug (DREADDs) are a novel tool with the potential to bidirectionally drive cellular, circuit, and ultimately, behavioral changes. We used DREADDs to evaluate memory formation in a hippocampusdependent task in mice and effects on synaptic physiology in the dorsal hippocampus. We expressed neuron-specific (hSyn promoter) DREADDs that were either excitatory (HM3D) or inhibitory (HM4D) in the dorsal hippocampus. As predicted, hSynHM3D was able to transform a subthreshold learning event into long-term memory (LTM), and hSyn-HM4D completely impaired LTM formation. Surprisingly, the opposite was observed during experiments examining the effects on hippocampal long-term potentiation (LTP). hSyn-HM3D impaired LTP and hSyn-HM4D facilitated LTP. Follow-up experiments indicated that the hSynHM3D-mediated depression of fEPSP appears to be driven by presynaptic activation of inhibitory currents, whereas the hSynHM4D-mediated increase of fEPSP is induced by a reduction in $\mathrm{GABA}_{\mathrm{A}}$ receptor function. To determine whether these observations were promoter specific, we next examined the effects of using the CaMKII $\alpha$ promoter that limits expression to forebrain excitatory neurons. CaMKII $\alpha$-HM3D in the dorsal hippocampus led to the transformation of a subthreshold learning event into LTM, whereas CaMKII $\alpha$-HM4D blocked LTM formation. Consistent with these findings, baseline synaptic transmission and LTP was increased in CaMKII $\alpha$-HM3D hippocampal slices, whereas slices from CaMKII $\alpha$-HM4D mice produced expected decreases in baseline synaptic transmission and LTP. Together, these experiments further demonstrate DREADDs as being a robust and reliable means of modulating neuronal function to manipulate long-term changes in behavior, while providing evidence for specific dissociations between LTM and LTP.

Key words: DREADDs; long-term memory formation; long-term potentiation; object location memory; object recognition memory; theta-burst stimulation

Significance Statement

This study evaluates the efficacy of designer receptors exclusively activated by designer drug (DREADDs) as a means of bidirectionally modulating the hippocampus in not only a hippocampus-dependent task but also in hippocampal synaptic plasticity. This is the first study to evaluate the effects of DREADD-mediated inhibition and excitation in hippocampal long-term potentiation. More specifically, this study evaluates the effect of promoter-specific expression of DREADD viruses in a heterogenic cell population, which revealed surprising effects of different promoters. With chemogenetics becoming a more ubiquitous tool throughout studies investigating circuit-specific function, these data are of broad interest to the neuroscientific community because we have shown that promoter-specific effects can drastically alter synaptic function within a specific region, without parallel changes at the level of behavior.

\section{Introduction}

Chemogenetics is providing a novel method of controlling and studying neural function. Specifically, designer receptors exclu- sively activated by designer drug (DREADDs) allow for a unique approach to investigate circuit activity of specific brain regions, circuits, and their role in driving behavior. DREADDs are a fam- 
ily of mutated muscarinic acetylcholine receptors that provide reversible activation of G-protein-coupled receptor (GPCR) signaling cascades on application of an otherwise inert ligand, clozapine- $n$-oxide (CNO). These receptors have no other active ligand, whereas $\mathrm{CNO}$ has no other active receptor, creating a two-way exclusive approach for activating $\left(\mathrm{G}_{\mathrm{s}}, \mathrm{G}_{\mathrm{q}}\right)$ or inhibiting $\left(G_{i}\right)$ cellular activity. $G_{i}, G_{q}$, and $G_{s}$ GPCR signaling cascades can be used for studying long-term cellular processing. As a result of this mechanism, DREADDs have diminished temporal resolution (because of both CNO metabolism and the temporal dynamics of GPCR) but are useful to study long-term processes. Activation of HM3Dq receptors induces internal $\mathrm{Ca}^{2+}$ waves through activation of PLC-dependent $\mathrm{IP}_{3}$ production. In this study, we use $\mathrm{G}_{\mathrm{q}}$-dependent signaling because of the known role activity-dependent $\mathrm{Ca}^{2+}$ plays in gene expression and learning and memory processes (Wu et al., 1995; Xia and Storm, 1997; Berridge et al., 1998; Wong et al., 1999; Pradhan and Liu, 2004). With regard to $G_{i}$ signaling, it is important to note that there are four major signaling processes potentially being negatively affected: (1) cAMP; (2) GIRK channels; (3) $\beta$-arrestin; and (4) $\mathrm{Ca}^{2+}$ (Armbruster et al., 2007; Rogan and Roth, 2011; Ferguson and Neumaier, 2014). Previous work has shown that these designer receptors can be effectively used to bidirectionally modulate neuronal activity in a spatially and temporally specific manner (Armbruster et al., 2007; Alexander et al., 2009; Dong et al., 2010a,b; Rogan and Roth, 2011; Lee et al., 2014; Zhu and Roth, 2014), yet the majority of this work has been focused on aspects of motivated behaviors and addiction (Ferguson et al., 2011; Nair et al., 2013; Ferguson and Neumaier, 2014). There has been a relatively limited focus in using DREADDs to study memory consolidation (Garner et al., 2012; Robinson et al., 2014; Sano et al., 2014; Zhu et al., 2014; Fortress et al., 2015; Ishii et al., 2015; Tsuda et al., 2015; Yau and McNally, 2015). Moreover, the literature investigating the effect of DREADD modulation on longterm potentiation (LTP), a form of synaptic plasticity, is limited, especially in the hippocampus. However, as this tool becomes more ubiquitously used, it is critical to have a clearer understanding of how DREADDs induce changes to synaptic function that consequentially alter learning and memory performance. In this study, we used a DREADD approach to investigate their ability to regulate hippocampal LTP and hippocampus-dependent longterm memory (LTM).

The novel object recognition (NOR) series of tasks have been widely used to assess memory formation (for review, see VogelCiernia and Wood, 2014). These tasks exploit rodents' inherent preference for novelty and can be used to study LTM formation in an incidental, noninvasive manner. Recent work, by our laboratory and others, has shown that the object location memory (OLM) task is a hippocampus-dependent task in rodents. Specifically, OLM requires the dorsal region of the CA1 subfield for LTM retrieval (Mumby, 2001; Mumby et al., 2002; Dere et al., 2007; Winters et al., 2008; Assini et al., 2009; Ennaceur, 2010; Barrett et al., 2011; Haettig et al., 2011; McQuown et al., 2011).

and MH81004, MH101491, DA025922, DA036984, and DA031989 (M.A.W.). We acknowledge the Roth Laboratory, particularly Dr. Bryan Roth, at the University of North Carolina (UNC) at Chapel Hill, whose efforts developing DREADD constructs made this work possible, and UNC Vector Core, particularly Dr. R. Jude Samulskifor providing viral vectors. We thank the National Institute of Mental Health Chemical Synthesis and Drug Supply Program for providing clozapine-n-oxide. Special thanks to Dr. John Guzowski of University of California, Irvine for use of the Olympus Scanner BX61VS for imaging.

Correspondence should be addressed to Dr. Marcelo A. Wood, University of California, Irvine, Department of Neurobiology and Behavior, 301 Qureshey Research Building, Irvine, CA 92697. E-mail: mwood@uci.edu.

DOI:10.1523/JNEUROSCI.3682-15.2016

Copyright $\odot 2016$ the authors $\quad 0270-6474 / 16 / 363589-12 \$ 15.00 / 0$
Conversely, retrieval of memory in the object recognition memory (ORM) task has been shown to be hippocampus independent in rodents, relying on cortical structures (Haettig et al., 2011, 2013; McQuown et al., 2011; Vogel-Ciernia et al., 2013). Here, we show that DREADDs in the dorsal hippocampus can be used to bidirectionally modulate LTM formation in the OLM task but not the ORM task. Surprisingly, however, we discovered promoter-specific effects of expressing DREADDs in the hippocampus on hippocampal LTP.

\section{Materials and Methods}

Animals. Eight-week old male C57BL/6 mice were purchased from The Jackson Laboratory. Animals were maintained in $12 \mathrm{~h} \mathrm{light/dark} \mathrm{cycle}$ with food and water provided ad libitum. All experiments were conducted according to the National Institutes of Health guidelines for animal care and use. Furthermore, experiments were approved by the Institutional Animal Care and Use Committee of the University of California, Irvine.

Stereotaxic surgeries. For hSyn-HM3D experiments, animals received $1 \mu \mathrm{l}$ of bilateral infusions to the dorsal hippocampus (ML, $\pm 1.5 \mathrm{~mm}$; AP, $-2.0 \mathrm{~mm}$; DV , $-1.5 \mathrm{~mm})$ of either AAV2.8-hSyn-GFP $(n=10-$ 12; viral titer, $3.7 \times 10^{12}$ ) control or AAV2.8-hSyn-HA-HM3D-IRES$m$ Citrine $\left(n=10-12 ; 2.3 \times 10^{12}\right)$. For hSyn-HM4D experiments, animals received similar infusions of either AAV2.8-hSyn-GFP $(n=$ $\left.10-12 ; 3.7 \times 10^{12}\right)$ control or AAV2.8-hSyn-HA-HM4D-IRES$m$ Citrine $\left(n=10-12 ; 4.2 \times 10^{12}\right)$. For CaMKII $\alpha-\mathrm{HM} 3 \mathrm{D}$ experiments, animals received $1 \mu \mathrm{l}$ of bilateral infusions to the dorsal hippocampus of either AAV2.8-CaMKII $\alpha-G F P\left(n=10-12 ; 5.6 \times 10^{12}\right)$ or AAV2.8CaMKII $\alpha-H A-H M 3 D-I R E S-m$ Citrine $\left(n=10-12 ; 3.1 \times 10^{12}\right)$. For CaMKII $\alpha$-HM4D experiments, animals received similar infusions of either AAV2.8-CaMKII $\alpha-G F P\left(n=10-12 ; 5.6 \times 10^{12}\right)$ or $A A V 2.8-$ CaMKII $\alpha-H A-H M 4 D$-IRES-mCitrine $\left(n=10-12 ; 3.3 \times 10^{12}\right)$. Viruses were infused at a rate of $6 \mu \mathrm{l} / \mathrm{h}$ using a 30 gauge Neuros Hamilton syringe (product \#65459-01) mounted to either a Harvard Apparatus Nanomite Syringe Pump (product \#MA1 70-2217) or Leica Biosystems Nanoinjector Motorized f/Stereotaxics (product \#39462901). All infusions used the Leica Microsystems Angle Two Stereotaxic system. Animals were allowed to recover for $7 \mathrm{~d}$ before handling. Behavioral testing and electrophysiological recordings began at day 21 after surgery, to allow for full expression of DREADD receptors. All viruses were purchased from the UNC Vector Core.

NOR tasks. NOR tasks were performed as described previously (VogelCiernia et al., 2013; Vogel-Ciernia and Wood, 2014). Briefly, animals were handled for 2 min over 5 consecutive days. Beginning on day 4 of handling, animals were habituated for $5 \mathrm{~min}$ to the OLM chamber for 6 consecutive days in the absence of the test objects. Animals then underwent a task training session. For HM3D experiments, animals were presented with two identical $100 \mathrm{ml}$ beakers for $3 \mathrm{~min}$. For HM4D experiments, animals were presented with these OLM training objects for $10 \mathrm{~min}$. Animals were injected systemically $40 \mathrm{~min}$ before the training session with $3 \mathrm{mg} / \mathrm{kg} \mathrm{CNO}$ (i.p., $0.3 \mathrm{mg} / \mathrm{ml}, 0.25 \%$ DMSO, $0.9 \%$ saline; made fresh daily). Animals were injected $40 \mathrm{~min}$ before behavior to allow for peak activation of DREADD receptors by CNO. After $24 \mathrm{~h}$, LTM formation was tested for $5 \mathrm{~min}$, in which the OLM training objects were presented, one of which in a novel location. After OLM testing, animals were allowed to recover for $5 \mathrm{~d}$. Animals were then habituated to the ORM chamber for 6 consecutive days in the absence of the test objects. For HM3D experiments, animals were presented with two identical objects (either metal tins or glass candle holders) for 3 min. For HM4D, animals were presented with these ORM training objects for $10 \mathrm{~min}$. Animals were injected systemically $40 \mathrm{~min}$ before the training session with $3 \mathrm{mg} / \mathrm{kg}$ CNO (i.p., $0.3 \mathrm{mg} / \mathrm{ml}, 0.25 \%$ DMSO, 0.9\% saline; made fresh daily). Twenty-four hours later, animals' retention was tested for 5 $\mathrm{min}$, in which one of the ORM training objects was replaced with a novel, previously unexplored object. Both the Training and Testing sessions were video recorded and hand scored by individuals blind to animal treatments. Videos were analyzed for total exploration of objects in addition to the discrimination index (DI) [(time spent exploring novel 
object - time spent exploring familiar object)/(total time exploring both objects)].

Tissue harvesting for immunohistochemistry and PCR. For HM3D experiments, at least $72 \mathrm{~h}$ after testing, both HM3D and GFP animals received a subsequent dose of $\mathrm{CNO}$, were returned to their home cage, and were killed after $70 \mathrm{~min}$. For HM4D experiments, at least $72 \mathrm{~h}$ after testing, animals received a subsequent dose of $\mathrm{CNO}$, were returned to their home cage for $40 \mathrm{~min}$, were introduced to a novel context for 10 $\mathrm{min}$, and were killed after $30 \mathrm{~min}$. Because the HM4D virus was predicted to inhibit hippocampal activity, it would be difficult to interpret this by simply giving a subsequent $\mathrm{CNO}$ injection and returning the animals to the home cage. This would lead to a floor effect because there would be very limited basal hippocampal activity and would be difficult to parse out differences between GFP and HM4D animals. The introduction to the novel context was an attempt to induce hippocampal activity, which presumably the HM4D virus would have inhibited. For immunohistological and c-fos expression experiments, animals were dislocated cervically, and the brains were flash frozen in chilled isopentane. Flash-frozen $20 \mu \mathrm{m}$ coronal sections and $500 \mu \mathrm{m}, 1.0 \mathrm{~mm}^{2}$ punches of CA1 subfield of dorsal hippocampus were collected using a Leica CM 1850 cryostat at $-18^{\circ} \mathrm{C}$. To examine c-fos expression, RNA was isolated from aforementioned punches using RNeasy Mini kit (catalog \#74106; Qiagen), and total RNA (50 ng) was reverse transcribed. cDNA was analyzed using Roche Light Cycler via Roche proprietary algorithms and REST 2009 software Pfaffl method (Pfaffl, 2001; Pfaffl et al., 2002). All values were normalized to GAPDH expression levels generated simultaneously. Both c-fos and gapdh primers were generated from the Roche Universal Probe Library; c-fos: left c-Fos primer, $5^{\prime}$-ggggcaaagtagagcagcta- $3^{\prime}$; right c-fos primer, $5^{\prime}$-agctccetcctccgattc- $3^{\prime}$; c-fos probe 46 , atggctgc; gapdh: right GAPDH primer, 5' -atggtgaaggtcggtgtga-3'; left GAPDH primer, 5' aatctccactttgccactgc- $3^{\prime}$; GAPDH probe, tggcggtattgg (Rogge et al., 2013). The c-Fos probe is conjugated to FAM, whereas the GAPDH probe is conjugated to Lightcycler Yellow 555. For verification of viral expression in electrophysiological experiments, RNA was isolated using RNeasy Mini kit (catalog \#74106; Qiagen), and total RNA was reverse transcribed. cDNA was analyzed using Bio-Rad MJ Mini-Personal Thermal Cycler for expression of either HM3D or HM4D viruses. Both HM3D and HM4D primers were generated from the Roche Universal Probe Library: hm3d: left HM3D primer, $5^{\prime}$-agtacaacctcgcctttgtttc- $3^{\prime}$; right HM3D primer, $5^{\prime}$-atcggaggggctgtgtatc- $3^{\prime}$; $h m 4 d$ : left primer, $5^{\prime}$-tgaagcagagcgtcaagaag- $3^{\prime}$; right HM4D primer, $5^{\prime}$-tcctccagcttgccattg- $3^{\prime}$.

Immunohistochemistry. To confirm expression of DREADD, flashfrozen sections were mounted to glass slides and stained for HA tag. Briefly, slices were fixed in 4\% PFA for $10 \mathrm{~min}$, washed twice in $0.1 \mathrm{M}$ PBS for $5 \mathrm{~min}$, and quenched in $1.5 \% \mathrm{H}_{2} \mathrm{O}_{2}$ for $20 \mathrm{~min}$. Tissue was permeated with a single 5 min wash in $0.1 \%$ Triton X-100 in PBS solution, washed in PBS three times for $5 \mathrm{~min}$, and blocked for $1 \mathrm{~h}$ in $8 \%$ normal goat serum (NGS) and $0.3 \%$ Triton X-100 in $0.1 \mathrm{M}$ PBS. After three 5-min PBS washes, slices were incubated overnight in an HA primary antibody solution containing anti-HA (1:1000, rat monoclonal, product \#11867423001; Roche Diagnostics), 2\% NGS, and 0.3\% Triton X-100 in $\mathrm{PBS}$ at $4^{\circ} \mathrm{C}$. Slices were washed three times for $5 \mathrm{~min}$ in PBS. Slices were then incubated in secondary solution (Alexa Fluor goat anti-rat 555 at $1: 1000,2 \%$ NGS, and $0.3 \%$ Triton X-100 in PBS) for $2 \mathrm{~h}$ at room temperature. After secondary incubation, slices were washed three times for 5 min in PBS, incubated in DAPI $(1: 15,000)$ in PBS, and washed in PBS three times. Slides were air dried and coverslipped with VectaShield Mounting Medium (product \#H-1000). Tissue was imaged using Olympus Scanner VSBX61 to confirm expression of either HA-tagged DREADD receptor or GFP control.

Hippocampal slice preparation and recording. Hippocampal slices were prepared as described previously (Barrett et al., 2011). Briefly, after isoflurane anesthesia, mice were decapitated, and the brain was quickly removed and submerged in ice-cold, oxygenated dissection medium containing the following (in mM): $124 \mathrm{NaCl}, 3 \mathrm{KCl}, 1.25 \mathrm{KH}_{2} \mathrm{PO}_{4}, 5$ $\mathrm{MgSO}_{4}, 26 \mathrm{NaHCO}_{3}$, and 10 glucose. Transverse hippocampal slices (375 $\mu \mathrm{m})$ through the mid-third of the septotemporal axis of the hippocampus were prepared using an FHC vibrating tissue slicer (model OTS5000) before being transferred to an interface recording chamber containing preheated artificial CSF (aCSF) of the following composition (in mM): $124 \mathrm{NaCl}, 3 \mathrm{KCl}, 1.25 \mathrm{KH}_{2} \mathrm{PO}_{4}, 1.5 \mathrm{MgSO}_{4}, 2.5 \mathrm{CaCl}_{2}, 26$ $\mathrm{NaHCO}_{3}$, and 10 glucose (maintained at $31 \pm 1{ }^{\circ} \mathrm{C}$ ). Slices were perfused continuously with this solution at a rate of $1-1.5 \mathrm{ml} / \mathrm{min}$ while the surface of the slices were exposed to warm, humidified $95 \% \mathrm{O}_{2} / 5 \% \mathrm{CO}_{2}$. Recordings began after at least $1.5 \mathrm{~h}$ of incubation.

Field EPSPs (fEPSPs) were recorded from CA1b stratum radiatum using a single glass pipette (2-3 M $\Omega$ ) filled with $2 \mathrm{M} \mathrm{NaCl}$. Stimulation pulses $(0.05 \mathrm{~Hz})$ were delivered to Schaffer collateral-commissural projections using a bipolar stimulating electrode (twisted nichrome wire, 65 $\mu \mathrm{m})$ positioned in CA1c. Current intensity was adjusted to obtain $50 \%$ of the maximal fEPSP response. In a separate set of experiments, antagonists of the AMPA and NMDA receptors were infused to block the negative-going fEPSP that is characteristic of excitatory transmission, leaving a positive-going evoked response that is blocked by picrotoxin (PTX), a GABA $\mathrm{A}_{\mathrm{A}}$ receptor antagonist (Lambert et al., 1991; Arai et al., 1995). This response is referred to as the field inhibitory postsynaptic potential (fIPSP). Input/output curves were established before testing began to adjust current intensity that produced near maximal responses.

After establishing a 10-20 min stable baseline, test compounds (see below) were introduced into the infusion line by switching from control aCSF to drug-containing aCSF. To determine whether CNO treatment affects the threshold level of LTP in slices from hSyn-GFP control, hSynHM3D, and hSyn-HM4D infused mice, LTP was induced by delivering three theta bursts, with each burst consisting of four pulses at $100 \mathrm{~Hz}$ and the bursts themselves separated by $200 \mathrm{~ms}$ [i.e., theta burst stimulation (TBS)]. The stimulation intensity was not increased during TBS. Data were collected and digitized by NAC 2.0 Neurodata Acquisition System (Theta Burst) and stored on a disk.

Reagents. For behavioral experiments, $\mathrm{CNO}$ was provided by the $\mathrm{Na}-$ tional Institute of Mental Health Chemical Synthesis and Drug Supply Program. For electrophysiological experiments, DNQX (Tocris Biosciences), D-(-)APV (Tocris Biosciences), and PTX (Sigma) were prepared fresh in aCSF, whereas a 10 mm stock solution of CNO (catalog \#141704; Abcam) was dissolved in water and subsequently diluted to a working concentration $(5 \mu \mathrm{M})$ in aCSF.

Data analysis. All statistical tests were performed using GraphPad Prism 5 (GraphPad Software). Habituation data (distance traveled during individual habituation sessions), training, and testing videos were collected using ANY-maze behavioral analysis software. Habituation was analyzed using a two-way ANOVA to compare total distance traveled across the habituation sessions. Training and testing data were analyzed using a Student's $t$ test to compare either exploration or DI between control and test animals. Slice physiology data in the text are presented as means \pm SD, and fEPSP slope was measured at $10-90 \%$ fall of the slope. Data in figures on LTP were normalized to the last $10 \mathrm{~min}$ of baseline and presented as mean \pm SE. CNO-induced changes on baseline measures were analyzed using a paired Student's $t$ test to compare the pre-CNO with post-CNO infusion period and assessed as significant if $p<0.05$. Baseline measures on paired-pulse facilitation and LTP were analyzed using a two-way ANOVA.

\section{Results}

\section{hSyn-HM3D-dependent activation of the dorsal hippocampus can transform subthreshold training into LTM in OLM, but not ORM}

To test whether activation of the dorsal hippocampus during a subthreshold training event can lead to LTM, hSyn-HM3D and hSyn-GFP infused animals received CNO 40 min before a 3 min training session. Human synapsin-1 is ubiquitously expressed throughout neurons, and viruses using the $h S y n$ promoter have been shown to have high neuron-specific expression (Kügler et al., 2003). We have shown previously that a 3 min training period is insufficient to generate LTM tested at $24 \mathrm{~h}$ (Stefanko et al., 2009; Haettig et al., 2011, 2013; McQuown et al., 2011). After CNO-primed training, animals were tested for LTM in the OLM task (Fig. 1A). hSyn-HM3D animals showed a significant in- 

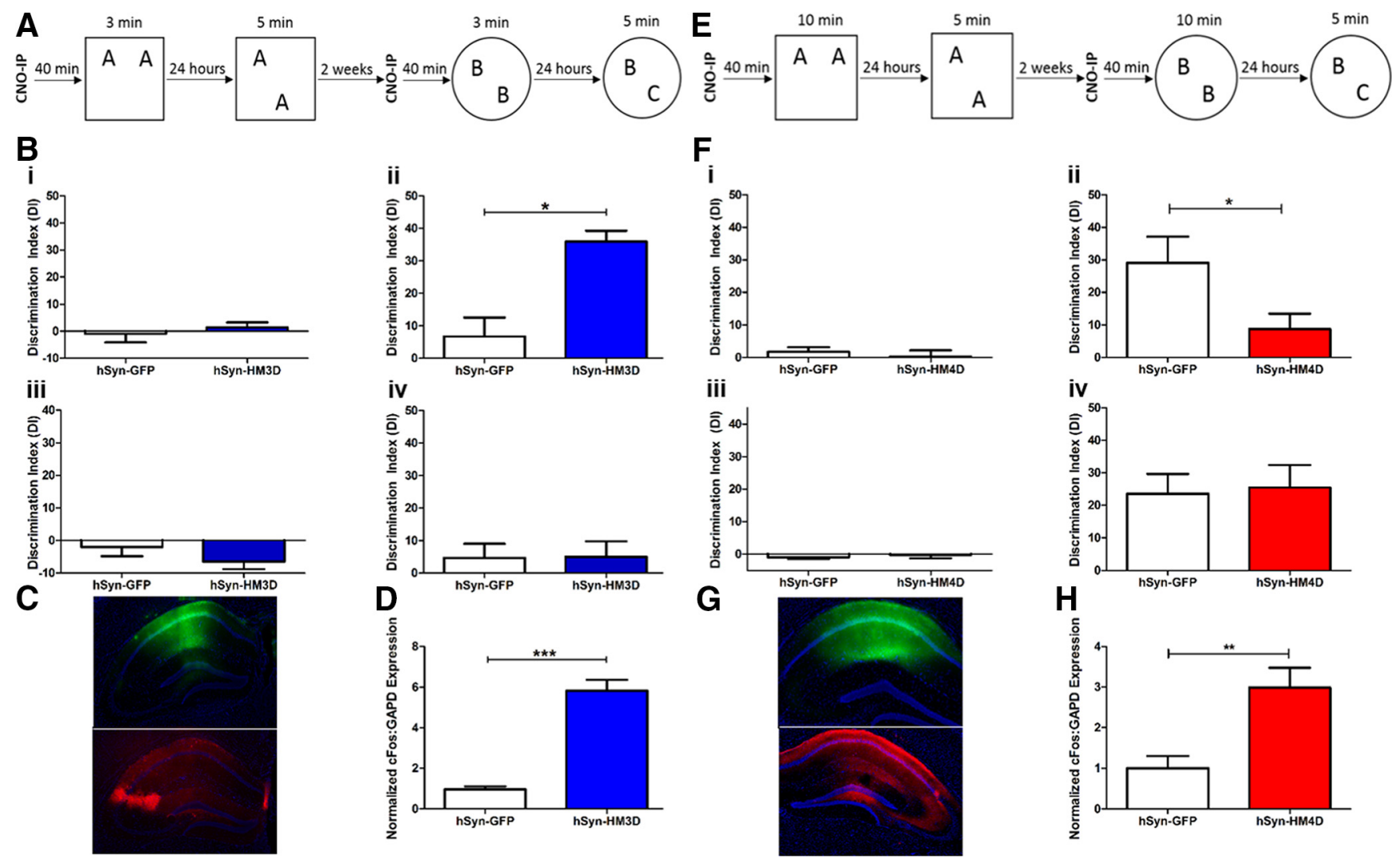

Figure 1. Bidirectional modulation of the dorsal hippocampus via hSyn-DREADDs affects LTM processes. A, Subthreshold training and testing paradigm for NOR tasks. $\boldsymbol{B}$, Training and testing Dls of hSyn-GFP (white) and hSyn-HM3D (blue), shown as mean \pm SEM. $\boldsymbol{i}$, Mean DI for OLM training. ii, Mean DI for OLM testing. iii, Mean DI for ORM training. iv, Mean DI for ORM testing. $\boldsymbol{C}$, Immunohistochemistry against DAPI (blue), GFP (green), and HA (red) in hSyn-GFP or hSyn-HM3D infused dorsal hippocampus. D, Normalized RT-qPCR measuring relative c-fos:GAPD expression in hSyn-GFP (white) and hSyn-HM3D (blue). $\boldsymbol{E}$, Threshold training and testing paradigm for NOR tasks. $\boldsymbol{F}$, Training and testing Dls of hSyn-GFP (white) and hSyn-HM4D (red), shown as mean \pm SEM. $\boldsymbol{i}$, Mean DI for OLM training. ii, Mean DI for OLM testing. iii, Mean DI for ORM training. iv, Mean DI for ORM testing. G, Immunohistochemistry against DAPI (blue), GFP (green), and HA (red) in hSyn-GFP or hSyn-HM4D infused dorsal hippocampus. $\boldsymbol{H}$, Normalized RT-qPCR measuring relative c-fos:GAPD expression in hSyn-GFP (white) and hSyn-HM4D (red). For HM3D 0LM and ORM experiments, $n=10$ forhSyn-GFP and $n=11$ forhSyn-HM3D. For HM4D OLM experiments, $n=11$ forhSyn-GFP and $n=12$ for hSyn-HM4D. For HM4D ORM experiments, $n=12$ forhSyn-GFP and $n=12$ for hSyn-HM4D. ${ }^{*} p \leq 0.05,{ }^{* *} p \leq 0.01,{ }^{* * *} p \leq 0.001$.

crease in DI compared with hSyn-GFP controls $\left(t_{(19)}=3.387\right.$, $p=0.0031)$ during the test session, demonstrating that HM3Dmediated activation in the hippocampus transforms a subthreshold training period into robust LTM for object location (Fig. 1Bii). There were no differences between groups in training DI (Fig. $\left.1 B i ; t_{(19)}=0.6511, p=0.5228\right)$, habituation $\left(F_{(1,5)}=\right.$ $0.02544, p=0.8749)$, training exploration $\left(t_{(19)}=1.083, p=\right.$ $0.2924)$, or test exploration $\left(t_{(19)}=0.2446, p=0.8094\right)$ in the OLM experiment (data not shown).

After testing in the OLM task, animals underwent a similar training and testing paradigm in the ORM task (Fig. 1A). hSynHM3D animals tested for LTM in the ORM task after CNOprimed training showed no difference in DI compared with hSyn-GFP controls $\left(t_{(19)}=0.05526, p=0.9565\right)$, demonstrating that HM3D-mediated activation in the hippocampus does not affect LTM for object recognition (Fig. 1Biv). There were no measurable differences between groups in training DI (Fig. 1Biii; $\left.t_{(19)}=1.240, p=0.23\right)$, habituation $\left(F_{(1,5)}=0.4782, p=0.4976\right)$, training exploration $\left(t_{(19)}=0.9064, p=0.3761\right)$, or test exploration $\left(t_{(19)}=0.5898, p=0.5623\right)$ in the ORM experiment (data not shown). Immunohistochemistry was used to verify expression of both hSyn-GFP and hSyn-HM3D viruses (Fig. 1C). To confirm in vivo expression and efficacy of hSyn-HM3D function, animals received a subsequent dose of $\mathrm{CNO}$ before being killed. RT-qPCR was used to measure c-fos expression in tissue collected from the dorsal hippocampus. Tissue expressing hSyn-HM3D showed a dramatic increase in normalized c-fos:GAPDH expression compared with hSyn-GFP control after a subsequent dose of CNO (Fig. 1D). These results suggest that activation of dorsal hippocampal neurons during training can transform a subthreshold learning event into LTM for OLM, a hippocampusspecific task, but not for ORM.

\section{hSyn-HM4D-dependent inactivation can block LTM formation in OLM, but not ORM}

To test whether dorsal hippocampus inactivation can block LTM formation during a training event that normally generates LTM, we administered CNO 40 min before 10 min training of hSynHM4D and hSyn-GFP infused animals. We have shown previously that a $10 \mathrm{~min}$ training period is sufficient for generating reliable LTM tested at $24 \mathrm{~h}$ (Stefanko et al., 2009; McQuown et al., 2011; Vogel-Ciernia et al., 2013; Vogel-Ciernia and Wood, 2014). Twenty-four hours after CNO-primed training, animals were tested for LTM in the OLM task (Fig. 1E). hSyn-HM4D animals showed a significant decrease in DI compared with hSyn-GFP controls $\left(t_{(22)}=2.177, p=0.0405\right)$ during the test session, demonstrating that HM4D-mediated inhibition of the dorsal hippocampus disrupts LTM for object location (Fig. 1Fii). There were no measurable differences between groups with regard to training DI (Fig. $1 F i ; t_{(22)}=0.6071, p=0.55$ ), habituation 


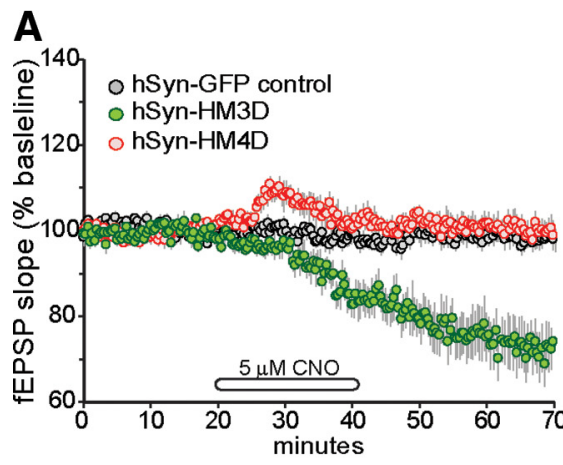

D

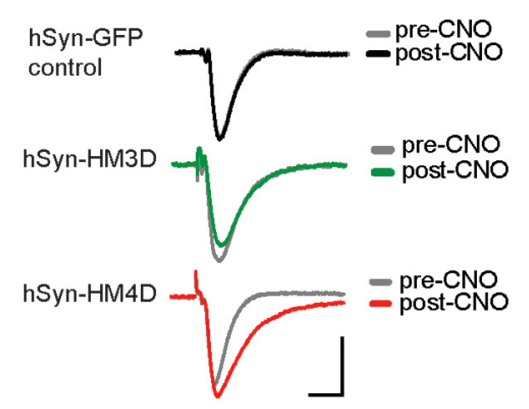

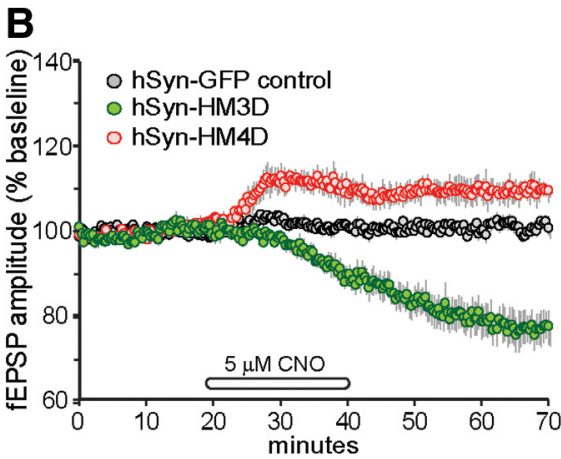

Ei, hSyn-GFP control mice

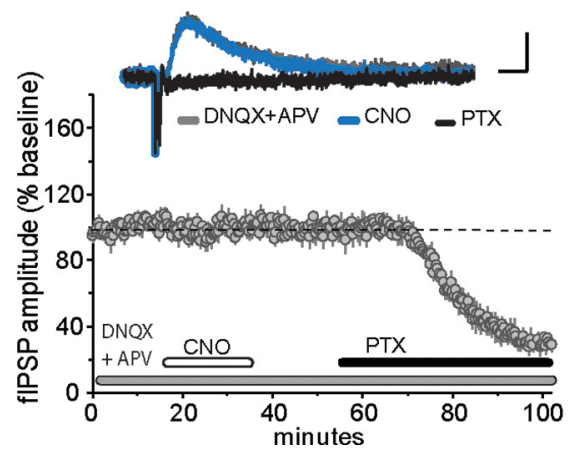

C

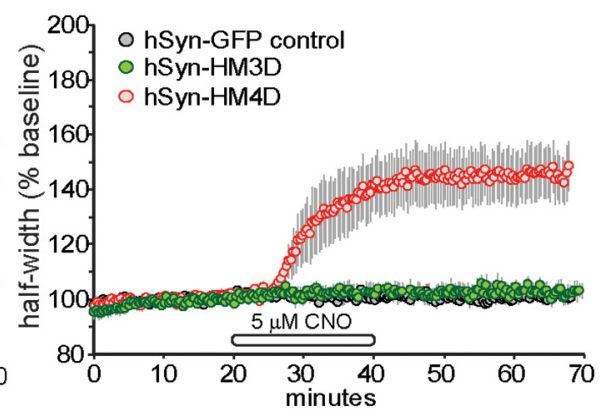

Eii, hSyn-HM3D and -HM4D mice

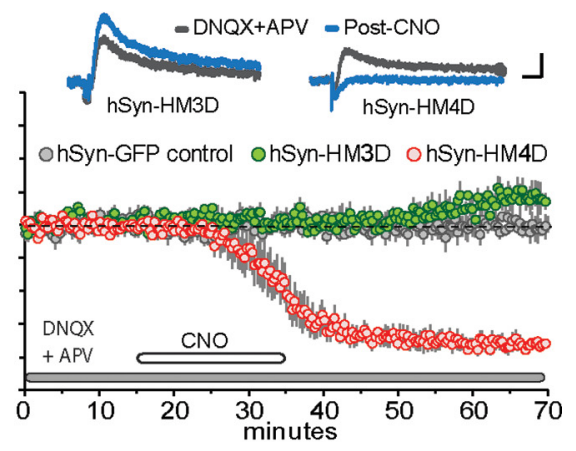

Figure 2. Characterization of baseline synaptic transmission in hippocampal slices expressing hSyn-driven excitatory and inhibitory DREADD receptors. $A-C$, Hippocampal slices were prepared from adult hSyn-GFP control (gray circles; $n=6$ ), hSyn-HM3D (green circles; $n=7$ ), and hSyn-HM4D (red circles; $n=6$ ) mice. The graphs show the mean \pm SEM fEPSP slope $(\boldsymbol{A})$, amplitude $(\boldsymbol{B})$, and half-width plotted as a percentage change of baseline $(\boldsymbol{C})$ in hippocampal slices treated for $20 \mathrm{~min}$ with $5 \mu \mathrm{M}$ CNO, followed by a washout. $\boldsymbol{D}$, Representative field responses collected from hSyn-GFP control, hSyn-HM3D, and hSyn-HM4D slices during the baseline recording period (pre-CNO) and $30 \mathrm{~min}$ after the end of CNO infusion (post-CNO). Calibration: $1 \mathrm{mV}, 5 \mathrm{~ms} . \boldsymbol{E}$, $\boldsymbol{i}$, Pharmacologically isolated fIPSP amplitudes (responses recorded in the presence of $20 \mu \mathrm{m}$ DNQX and $100 \mu \mathrm{m}$ APV, antagonists for AMPA and NMDA receptors, respectively) were evoked by stimulation of the Schaffer-commissural projections (pre-CNO, gray line, top trace) in slices prepared from hSyn-GFP control animals ( $n=5$ slices). Graph shows the mean \pm SEM change in fIPSP amplitude as a percentage change of baseline. These responses were completely blocked by the GABA $A_{A}$ receptor antagonist PTX (black line, top traces) and were unaffected by infusions of $5 \mu \mathrm{m}$ CNO (blue line, top traces). Calibration: $0.1 \mathrm{mV}, 10 \mathrm{~ms}$. ii, In slices prepared from hSyn-HM3D mice ( $n=7$ slices), CN0 infusions produced a delayed but significant increase in the fIPSP. In contrast, CN0 infusions mimicked the effects of PTX by causing a dramatic decrease in the fIPSP and completely eliminating the field response 30 min after the end of the infusion period in slices $(n=5)$ from hSyn-HM4D mice. fIPSPs were unaffected by infusions of CNO in slices from hSyn-GFP controls $(n=5)$ during the recording session. Calibration: $0.1 \mathrm{mV}, 10 \mathrm{~ms}$.

$\left(F_{(1,5)}=0.3796, p=0.5441\right)$, training exploration $\left(t_{(22)}=0.4126\right.$, $p=0.6839)$, or test exploration $\left(t_{(22)}=1.934, p>0.05\right)$ in the OLM experiment (data not shown).

After testing in the OLM task, animals underwent a similar behavioral paradigm for the ORM task (Fig. 1E). hSyn-HM4D animals tested for LTM in the ORM task after CNO-primed training showed no difference in DI compared with hSyn-GFP controls $\left(t_{(21)}=0.2171, p=0.8302\right)$, demonstrating that HM4Dmediated inhibition of the dorsal hippocampus does not affect LTM for object recognition (Fig. 1Fiv). There were no measurable differences between groups in training DI (Fig. 1Fiii; $t_{(21)}=$ 0.5423, $p=0.5933)$, habituation $\left(F_{(1,5)}=0.3923, p=0.5379\right)$, training exploration $\left(t_{(21)}=1.034, p=0.3127\right)$, or test exploration $\left(t_{(21)}=0.9842, p=0.3362\right)$ in the ORM experiment (data not shown). Together, these results indicate that inhibition of dorsal hippocampal activity during robust training, which is sufficient for LTM, can block the formation of LTM for OLM, but not for ORM. Expression of hSyn-GFP and hSyn-HM4D viruses was confirmed immunohistologically (Fig. 1G). However, to confirm in vivo efficacy of hSyn-HM4D function, animals received a subsequent dose of CNO, and RT-qPCR was used to measure c-fos expression in tissue collected from the dorsal hippocampus. Surprisingly, tissue expressing hSynHM4D also showed a dramatic increase in normalized c-fos: GAPDH expression compared with hSyn-GFP control after a subsequent dose of $\mathrm{CNO}$ (Fig. $1 H$ ). The cause of this c-fos induction is unknown and could be attributed to several factors, including interneuron function throughout the dorsal hippocampus. To more accurately characterize the hSynmediated effects on hippocampal function, we evaluated DREADD modulation electrophysiologically.

\section{hSyn-dependent expression of DREADD receptors} differentially affects synaptic transmission and LTP in hippocampal field CA1

We predicted that glutamatergic synaptic transmission involving the activation of $\mathrm{G}_{\mathrm{q}}$-mediated signaling pathways after $\mathrm{CNO}$ infusions would increase synaptic transmission and LTP in hippocampal slices expressing hSyn-HM3D DREADD receptors (Greget et al., 2011; Roggenhofer et al., 2013; Suárez et al., 2014). The opposite effects on synaptic transmission and LTP were predicted for CNO-induced excitatory synaptic transmission involving the activation of the inhibitory signaling pathways associated with $\mathrm{G}_{\mathrm{i}}$-mediated pathways regulated by hSyn-HM4D DREADD receptors (DeBock et al., 2003; Bailey et al., 2008). We tested these predictions in acute hippocampal slices prepared from hSynGFP control, hSyn-HM3D, and hSyn-HM4D infused mice. The effects of a 20 min infusion of CNO ( $5 \mu \mathrm{M})$ on fEPSPs and fIPSPs recorded in the apical dendrites of hippocampal region CA1 are summarized in Figure 2. CNO infusions had no detectable influence on fEPSP slope and amplitude in slices from hSyn-GFP animals (Fig. 2A,B). 


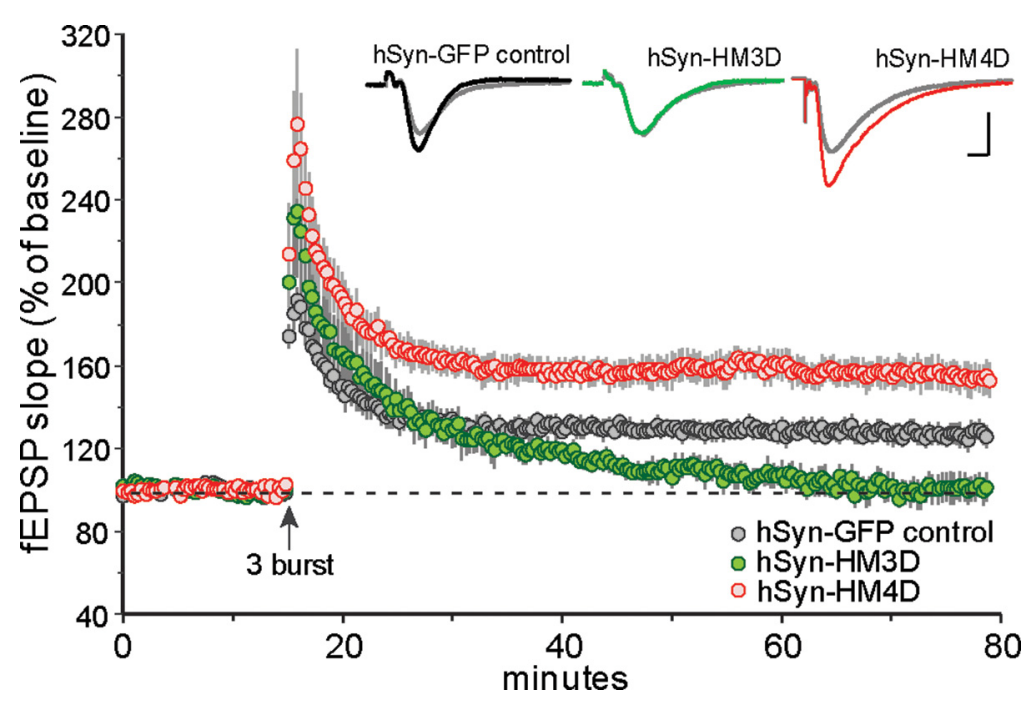

Figure 3. Long-term plasticity changes associated with hSyn-driven DREADD receptor expression in adult hippocampal slices. The slope of the fEPSP was normalized to the mean of the last 60 responses ( $10 \mathrm{~min}$ ) collected in the presence of $5 \mu \mathrm{m}$ CNO before application of TBS (upward arrow). A single train of three theta bursts was effective in inducing stable potentiation in slices from hSyn-GFP control mice $(n=6)$ but produced a supranormal amount of potentiation in slices from hSyn-HM4D mice $(n=6)$. In contrast, theta burst-induced LTP decayed toward baseline values in slices from hSyn-HM3D $(n=6)$ mice. Inset, Traces collected during the last 5 min of CNO treatment (gray line) and 60 min after TBS (black, green, and red lines). Calibration: $1 \mathrm{mV}, 5 \mathrm{~ms}$.

all, of the CNO-induced increases described above. To test this possibility, we pharmacologically isolated the fIPSP to test $\mathrm{CNO}$-induced effects on inhibitory currents in hSyn-HM4D slices. As described in previous reports studying fIPSP in slices (Lambert et al., 1991; Arai et al., 1995), a PTX-sensitive response recorded in the presence of AMPA and NMDA receptor antagonists yields a positive-going fIPSP in slices from hSyn-GFP control mice as shown in Figure 2Ei. After a stable baseline recording, the fIPSP remained unchanged during the $20 \mathrm{~min} \mathrm{CNO}$ infusion period in control slices. After a brief washout period, $100 \mu \mathrm{M}$ PTX was added to the infusion line to confirm that the positive-going potential is the extracellular reflection of an IPSP. As illustrated, infusions of PTX completely eliminated the isolated fIPSP (Fig. 2Ei). We then tested CNO effects on the fIPSP in slices prepared from hSyn-HM3D and hSynHM4D mice (Fig. 2Eii). As anticipated, CNO-treated slices from hSyn-HM4D

Unexpectedly, CNO-treated slices from hSyn-HM3D mice caused a substantial decrease in the slope $\left(-28 \pm 14 \%, t_{(6)}=5.3\right.$, $p=0.0018)$ and amplitude $\left(-17 \pm 9 \%, t_{(6)}=4.4, p=0.004\right)$ of the fEPSP relative to pre-CNO infusion (Fig. $2 A, B, D$ ). Field responses in slices from hSyn-HM4D mice also produced surprising results (Fig. 2A,B,D). CNO treatment caused a transient increase in slope, whereas the amplitude of the field response remained significantly elevated $20 \mathrm{~min}$ into the washout period relative to pre-CNO baseline values $\left(9 \pm 5 \%, t_{(5)}=4.5, p=\right.$ $0.006)$. The sustained increase in fEPSP amplitude is likely attributable to the onset of a change in half-width that can cause changes in waveform as described below. The enhanced responses after CNO infusion in hSyn-HM4D slices was not accompanied by changes in paired-pulse facilitation when compared with pre-CNO treatment $\left(F_{(1,27)}=0.32, p=0.37\right)$, but a notable increase was observed at the shortest interval tested in hSyn-HM3D slices $\left(F_{(1,21)}=5.6, p<0.001\right)$. Thus, viral expression of DREADD receptors driven by the hSyn promoter in the hippocampus appears to recruit various cell types that mask the desired effects on synaptic transmission and suggests that CNOinduced decrease in synaptic transmission may involve changes in presynaptic function in hSyn-HM3D mice.

It is important to note that, unlike field responses recorded from hSyn-GFP control and hSyn-HM3D animals, the fEPSP in slices from hSyn-HM4D was accompanied by a significant broadening of the evoked potential (half-width, $45 \pm 23 \%$; Fig. $2 C, D)$. This measure was significantly greater in hSyn-HM4D slices $\left(t_{(5)}=4.5, p=0.006\right)$ compared with slices from hSyn$\operatorname{HM} 3 \mathrm{D}\left(3 \pm 8 \%, t_{(6)}=1.1, p=0.31\right)$ and GFP control $(1 \pm 4 \%$, $\left.t_{(9)}=0.77, p=0.46\right)$ mice. The dramatic change in response waveform induced by $\mathrm{CNO}$ infusion in this group of animals suggests that the $\mathrm{CNO}$-induced effect on field responses were not selective to glutamate receptors but rather included a $G A B A_{A}$ receptor component that mediates feedforward inhibition. The fast feedforward IPSP disynaptically activated by the Schaffercommissural fibers affects the amplitude and waveform of the fEPSP (Alger and Nicoll, 1982; Grover and Yan, 1999). Therefore, changes in these potentials could account for some, although not mice caused a dramatic decrease in the fIPSP beginning 10-15 min after the start of infusion and ultimately completely blocked fIPSP 30 min into washout. In contrast, bath applications of CNO did not cause an immediate, but rather a delayed, increase on fIPSP in slices from hSyn-HM3D mice. The increase in the fIPSP began $10-15 \mathrm{~min}$ into the washout period and reached a significant level by the end of the testing period $\left(14 \pm 12 \%, t_{(5)}=3.0\right.$, $p=0.03)$. CNO infusions did not alter fIPSPs in slices from hSyn-GFP controls during the duration of the experimental session. Collectively, these results suggest that, on one hand, the hSyn for the HM4D DREADD is increasing excitatory drive in hippocampal subfield CA1 by reducing inhibitory tone, whereas on the other hand, the HM3D DREADD is decreasing excitatory transmission on synaptic inputs to CA1 by increasing inhibitory tone.

We then were interested in determining whether the hSynDREADD receptor effects on synaptic transmission would remain consistent with predicted outcomes for changes in long-term plasticity. That is, would CNO-treated slices from hSyn-HM3D and hSyn-HM4D mice show impaired and enhanced LTP, respectively? Because the hSyn-HM4D animals appeared to have a reduction in GABAergic transmission (Fig. $2 C$,Eii), we used a subthreshold level of stimulation to induce LTP that consisted of a train of three theta bursts. Figure 3 summarizes the effects of theta burst-induced LTP in slices from hSyn-HM3D and hSyn-HM4D with respect to hSyn-GFP mice. TBS in CNO-treated slices from hSyn-GFP injected mice produced strong short-term potentiation that gradually stabilized over a $20 \mathrm{~min}$ period to a level that was $27 \pm 12 \%$ above pre-TBS baseline $60 \mathrm{~min}$ after induction. This is in agreement with previous work showing that subthreshold levels of theta stimulation can produce lasting potentiation in mouse hippocampal slices (Vogel-Ciernia et al., 2013). In accordance with CNO-induced effects on baseline transmission in hSyn-HM4D mice, TBS caused a marked enhancement in LTP in this group of CNOtreated slices $(55 \pm 18 \%)$, whereas LTP failed to stabilize in CNO-treated slices from hSyn-HM3D mice $(0 \pm 14 \%)$. The enhancement in LTP in hSyn-HM4D slices is consistent with pre- 

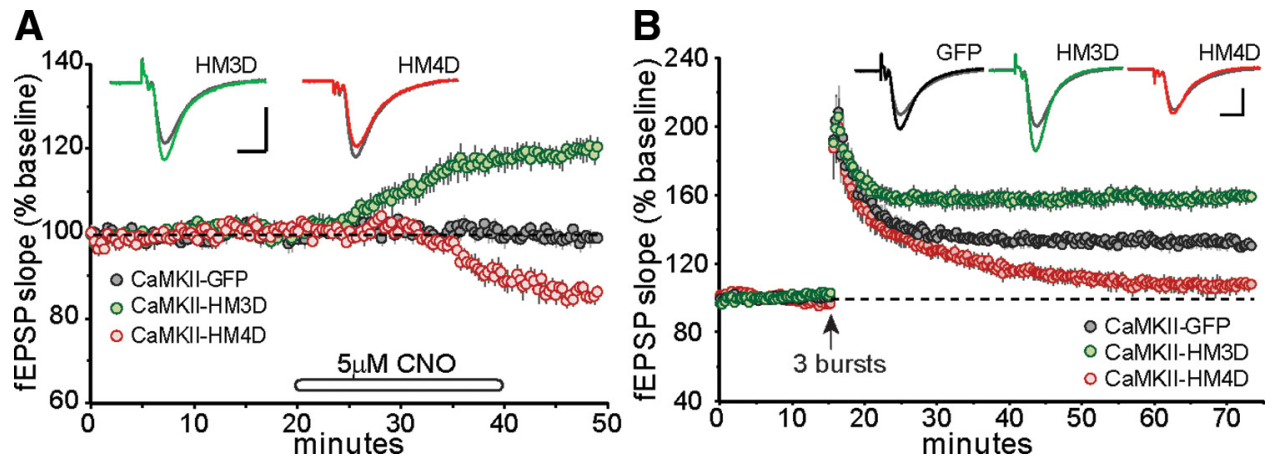

Figure 4. Promotor-specific effects of CaMKII $\alpha$ DREADD receptors on synaptic transmission and long-term plasticity. $A$, After stable baseline recordings, infusions of CNO (5 $\mu \mathrm{M}$ ) produced a rapid increase in field responses collected from CaMKII $\alpha-$ HM3D $(n=8)$ slices. In contrast, CNO infusions caused a marked decrease in fEPSP slope in slices from CaMKII $\alpha$-HM4D ( $n=6)$ mice. Field responses from CaMKII $\alpha$-GFP $(n=6)$ slices were unaffected by CNO infusion. Inset, Representative traces collected during baseline recording ( $g r a y ~ l i n e)$ and 10 min after the end of CNO infusion (colored lines). Calibration: $1 \mathrm{mV}, 5 \mathrm{~ms}$. B. The slope of the fEPSP was normalized to the mean of the last 60 responses ( $10 \mathrm{~min}$ ) collected in the presence of $5 \mu \mathrm{m}$ CNO before application of TBS (upward arrow). A single train of three theta bursts delivered at the end of $\mathrm{CNO}$ infusion period was sufficient to induce short-term potentiation that then stabilized for the remainder of the recording period in control slices (CaMKII $\alpha$-GFP, $n=6$ ) but not in slices from CaMKII $\alpha$-HM4D $(n=6)$. The same train applied at the end of the CNO infusion generated robust and stable LTP that was greater in magnitude in slices from CaMKII $\alpha$-HM3D $(n=8)$ mice than controls. Inset, Traces collected during the last 5 min of CNO treatment (gray line) and 60 min after TBS (black, green, and red lines). Calibration: $1 \mathrm{mV}, 5 \mathrm{~ms}$.

vious studies showing that blocking $\mathrm{GABA}_{\mathrm{A}}$ receptor activation enhances LTP in area CA1 (Chapman et al., 1998; Grover and Yan, 1999). The difference between groups of slices with CNO was significantly different $60 \mathrm{~min}$ after TBS (Fig. $3 ; F_{(2,15)}=73$, $p=0.001)$. To confirm viral infusions in hSyn-HM3D and hSyn-HM4D slices, PCR on collected tissue was used with primers specific to either HM3D or HM4D receptors to rule out the possibility of crossed viral infusion, i.e., to validate that the inhibitory effect of the hSyn-HM3D virus was not attributable to being accidentally injected with hSyn-HM4D but is truly a characteristic of the hSyn-HM3D virus and vice versa. PCR with primers specific to the HM3D virus yielded bands only in tissue isolated from HM3D animals. Moreover, PCR with primers specific to the HM4D virus yielded bands only in tissue isolated from HM4D animals, thus precluding the possibility of virus crosscontamination (data not shown). Together, these studies strongly suggest that the hSyn promoter virus is transducing a global population of neurons in hippocampal region CA1 that regulate both excitatory and inhibitory synaptic inputs, thus making it difficult to interpret behavioral results on learning and memory.

Targeting the excitatory cell population via promoter specificity corrects for predicted outcome on synaptic transmission and long-term plasticity

Use of the CaMKII $\alpha$ promoter has been shown to restrict viral expression to forebrain excitatory neurons (Mayford et al., 1996; Dittgen et al., 2004; White et al., 2011; Scheyltjens et al., 2015). Thus, we predicted that animals infused with the CaMKII $\alpha$ regulated HM3D and HM4D DREADD receptors would alter excitatory transmission in a positive and negative manner, respectively. In agreement with our hypotheses, bath-applied CNO $(5 \mu \mathrm{M})$ caused a rapid increase in glutamatergic transmission beginning 5-10 min after the start of infusion in slices prepared from animals treated with CaMKII $\alpha-H M 3 D$ (Fig. $4 A$ ). This effect was highly reproducible and consisted of a $20 \%$ increase over baseline by $30 \mathrm{~min}$ after the start of infusion. It is noteworthy to mention that there were no dramatic changes in the duration of the fEPSP (for comparison, see hSyn-HM4D; Fig. 2E,D). The opposite result was obtained with a $20 \mathrm{~min}$ application of $\mathrm{CNO}$ in slices from CaMKII $\alpha$-HM4D infused mice; CNO caused a significant drop, albeit more gradual, in fEPSP slope that was $15 \%$ below baseline values, whereas the synaptic responses collected from CaMKII $\alpha$-GFP control slices remained unchanged during the infusion and recording session. (Fig. 4A). The change in responses after CNO infusion of CaMKII $\alpha-\operatorname{HM} 3 \mathrm{D}\left(F_{(1,21)}=3.7\right.$, $p=0.0003)$ was accompanied by changes in paired-pulse facilitation, as was in slices from the CaMKII $\alpha-\mathrm{HM} 4 \mathrm{D}$ group $\left(F_{(1,15)}=5.0, p<0.001\right)$, suggesting that $\mathrm{CNO}$-induced changes in baseline are mediating transmitter release kinetics.

We then tested the effects of CNO on theta burst-induced LTP in CaMKII $\alpha-H M 3 D$ and CaMKII $\alpha-H M 4 D$ infused mice (Fig. 4B). Consistent with our previous predictions, the delivery of three theta bursts in the presence of $\mathrm{CNO}$ produced stable potentiation in slices from CaMKII $\alpha-$ GFP mice (32 \pm $7 \%$ ) but generated robust LTP when delivered to slices with CaMKII $\alpha-$ HM3D $(59 \pm 11 \%)$. The opposite was found in slices with $\mathrm{CaMKII} \alpha-\mathrm{HM} 4 \mathrm{D}$ in which potentiation failed to stabilize $30 \mathrm{~min}$ after induction and continued to drop toward baseline levels $60 \mathrm{~min}$ after TBS $(7 \pm 10 \%)$. The differences between groups were highly significant $\left(F_{(2,17)}=81, p<\right.$ $0.001)$. Post hoc tests revealed that LTP was increased reliably in slices from CaMKII $\alpha-\mathrm{HM} 3 \mathrm{D}$ mice and reduced in $\mathrm{CNO}$ treated slices from CaMKII $\alpha-\mathrm{HM} 4 \mathrm{D}$ mice.

CaMKII $\alpha$-HM3D-dependent activation of dorsal hippocampus can transform subthreshold training into LTM in OLM, but not ORM

Although the effects of CaMKII $\alpha-\mathrm{HM} 3 \mathrm{D}$ excitation of the dorsal hippocampus on LTP were as predicted, it was necessary to compare these hippocampal synaptic plasticity results with those of hippocampal learning. To test whether CaMKII $\alpha$-HM3D-mediated excitation of the dorsal hippocampus can transform a subthreshold training event into LTM, CaMKII $\alpha-$ HM3D and CaMKII $\alpha-$ GFP infused animals received CNO $40 \mathrm{~min}$ before a 3 min training session (Fig. $5 A$ ). Twenty-four hours after $\mathrm{CNO}$-coupled training, animals were tested for LTM in the OLM task. CaMKII $\alpha-\mathrm{HM} 3 \mathrm{D}$ animals showed a significant increase in DI compared with CaMKII $\alpha-$ GFP controls $\left(t_{(21)}=4.774, p=0.0001\right)$, demonstrating that HM3D-mediated excitation in the hippocampus transforms a subthreshold training period into robust LTM for object location (Fig. 5Bii). There were no significant differences between groups in training DI (Fig. $5 B i ; t_{(21)}=0.01476, p=0.9884$ ) or 

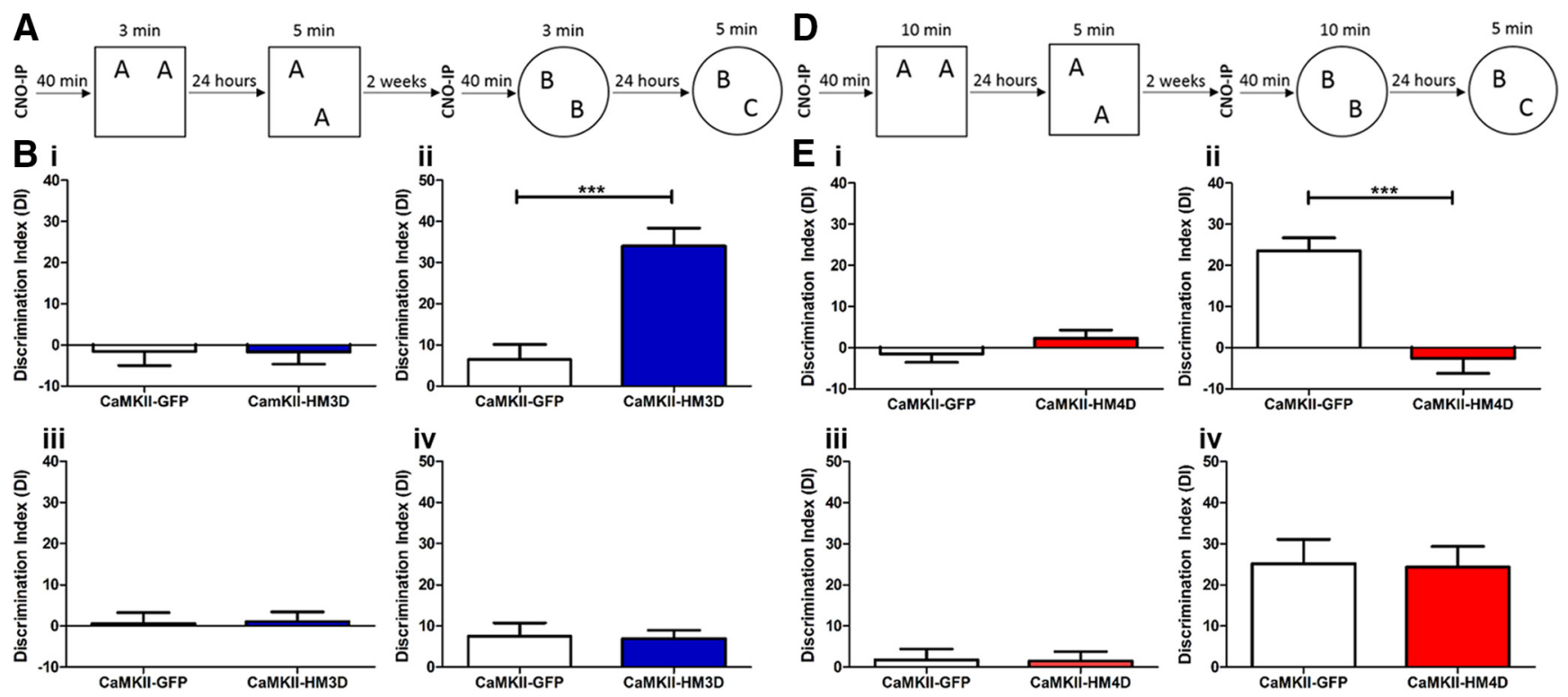

C

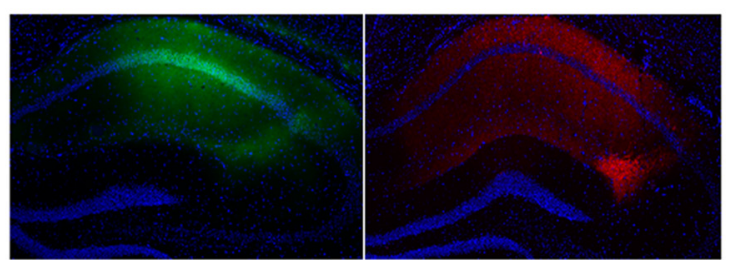

$\mathbf{F}$

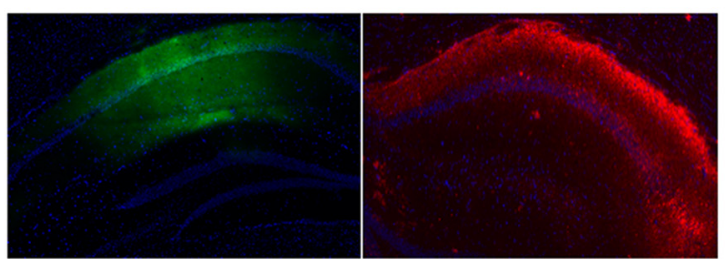

Figure 5. Modulation of dorsal hippocampus via CaMKII $\alpha$-DREADDs leads to bidirectional changes in LTM processes. A, Subthreshold training and testing paradigm for NOR task. $\boldsymbol{B}$, Training and testing Dl of CaMKII $\alpha-$ GFP (white) and CaMKII $\alpha-$ HM3D (blue), shown as mean \pm SEM. i, Mean DI for OLM training. ii, Mean DI for OLM testing. iii, Mean DI for ORM training. iv, Mean DI for ORM testing. C, Immunohistochemistry against DAPI (blue), GFP (green), and HA (red) in CaMKIl $\alpha$-GFP or CaMKIl $\alpha$-HM3D infused dorsal hippocampus. D, Threshold training and testing paradigm for NOR task. E, Training and testing Dl of CaMKIll $\alpha-G F P$ (white) and CaMKIl $\alpha-H M 4 D$ (red), shown as mean \pm SEM. $i$, Mean DI for OLM training. ii, Mean DI for OLM testing. iii, Mean DI for ORM training. iv, Mean DI for ORM testing. $\boldsymbol{F}$, Immunohistochemistry against DAPI (blue), GFP (green), and HA (red) in CaMKIl $\alpha$-GFP or CaMKII $\alpha$-HM4D infused dorsal hippocampus. For HM3D 0LM and ORM experiments, $n=11$ for CaMKII $\alpha$-GFP and $n=12$ for CaMKII $\alpha$-HM3D. For HM4D OLM experiments, $n=12$ for CaMKII $\alpha$-GFP and $n=11$ for CaMKIII $\alpha$-HM3D. For HM4D ORM experiments, $n=12$ for CaMKIl $\alpha-$ GFP and $n=12$ for CaMKII $\alpha-$ HM3D. ${ }^{* * *} p \leq 0.001$.

test exploration $\left(t_{(21)}=1.298, p=0.2082\right.$; data not shown). However, there was a modest, yet statistically significant, increase in CaMKII $\alpha-\mathrm{HM} 3 \mathrm{D}$ animals' training exploration $(7.891 \pm 0.3704 \mathrm{~s})$ compared with CaMKII $\alpha-$ GFP (6.394 \pm $\left.0.4156 \mathrm{~s} ; t_{(21)}=2.698, p=0.0135\right)$. Furthermore, there was a significant difference in habituation $\left(F_{(1,5)}=4.821, p=\right.$ $0.0395)$. However, a Bonferroni's post hoc test revealed that the difference was only significant during day 1 of habituation and was no longer significant throughout days $2-6$, suggesting that both groups of animals equally habituated to the OLM training context before training (data not shown).

After OLM testing, animals were subsequently trained and tested in the ORM task (Fig. 5A). CaMKII $\alpha-$ HM3D and CaMKII $\alpha-$ GFP animals tested for LTM in the ORM task $24 \mathrm{~h}$ after CNO-primed training showed no difference in DI compared with CaMKII $\alpha-$ GFP controls (Fig. 5 Biii; $_{(21)}=0.1542$, $0.8789)$, with no measureable differences in habituation $\left(F_{(1,5)}=3.276, p=0.0846\right)$, training DI (Fig. 5Bii; $t_{(21)}=$ $0.1478, p=0.8839)$, training exploration $\left(t_{(21)}=1.079, p=\right.$ $0.2928)$, or test exploration $\left(t_{(21)}=1.079, p=0.2928\right.$; data not shown). Expression of either CaMKII $\alpha-$ GFP or CaMKII $\alpha-$ HM3D in the dorsal hippocampus was confirmed immunohistologically (Fig. 5C). These results indicate that CaMKII $\alpha$-HM3D-mediated excitation of the dorsal hippocampus parallels the electrophysiological effects on LTP and is able to transform the subthreshold training event into LTM for the OLM task, but not the ORM task.

\section{CaMKII $\alpha$-HM4D-dependent inactivation of the dorsal} hippocampus can block LTM formation in OLM, but not ORM

To test whether CaMKII $\alpha$-HM4D-mediated inhibition of dorsal hippocampal neurons can disrupt LTM formation, we primed 10 min training of CaMKII $\alpha-\mathrm{HM} 4 \mathrm{D}$ or CaMKII $\alpha-$ GFP infused animals with CNO administration. Twenty-four hours after CNOcoupled training, animals were tested for LTM in the OLM task (Fig. 5D). CaMKII $\alpha$-HM4D animals showed a significant decrease in DI compared with CaMKII $\alpha-$ GFP controls (Fig. 5Eii; $\left.t_{(21)}=5.490, p<0.0001\right)$, with no significant differences in training DI (Fig. $5 E i$; $\left.t_{(21)}=1.296, p=0.2090\right)$, habituation $\left(F_{(1,5)}=\right.$ $0.0569, p=0.8136)$, training exploration $\left(t_{(21)}=0.4539, p=\right.$ $0.6545)$, or test exploration $\left(t_{(21)}=0.5871, p=0.5634\right.$; data not shown).

Animals were subsequently tested for LTM in the ORM task $24 \mathrm{~h}$ after $\mathrm{CNO}$-primed training (Fig. 5D). CaMKII $\alpha-\mathrm{HM} 4 \mathrm{D}$ animals showed no differences in testing DI compared with CaMKII $\alpha$-GFP controls (Fig. 5Eiv; $t_{(22)}=0.1125, p=0.9114$ ). Moreover, there were no measurable differences in training DI (Fig. 5Eiii; $\left.t_{(22)}=0.07847, p=0.9382\right)$, habituation $\left(F_{(1)}=\right.$ $0.2521, p=0.6206)$, training exploration $\left(t_{(22)}=0.6564, p=\right.$ $0.5184)$, or test exploration $\left(t_{(22)}=0.8065, p=0.4286\right.$; data not shown). Immunohistochemistry was used to confirm expression of CaMKII $\alpha-$ GFP or CaMKII $\alpha-$ HM4D (Fig. $5 F$ ). These results suggest that CaMKII $\alpha$-HM4D-mediated inhibition of the dorsal hippocampus parallels the electrophysiological effects on LTP 
and is able to prevent the formation of LTM for the OLM task, but not the ORM task.

\section{Discussion}

We implemented DREADDs to bidirectionally modulate the dorsal area of the hippocampus to understand the effect of DREADD-dependent modulation of hippocampus-dependent LTM and hippocampal LTP. Both hSyn-HM3D- and CaMKII $\alpha-$ HM3D-mediated activation of the dorsal hippocampus was able to transform a subthreshold learning event into LTM for object location, but not object recognition. Additionally, hSyn-HM4Dand CaMKII $\alpha$-HM4D-mediated inactivation of the same region was able to block LTM formation for object location, but not object recognition. These behavioral results support previous findings in mice that the dorsal hippocampus appears to be particularly involved in OLM, but not object recognition (Mumby et al., 2002; Assini et al., 2009; Barrett et al., 2011; Haettig et al., 2011; Vogel-Ciernia et al., 2013; Vogel-Ciernia and Wood, 2014). Memory for object recognition appears to be more dependent on the perirhinal cortex (Winters et al., 2004; Winters and Bussey, 2005; Balderas et al., 2008) and the insular cortex (BermudezRattoni et al., 2005; Balderas et al., 2008). However, the role of the hippocampus in memory for object recognition is more controversial (Mumby, 2001; Dere et al., 2007), because results tend to be dependent on various parameters and time between training and testing (Rossato et al., 2007; Balderas et al., 2008; Haettig et al., 2011).

It is possible that there are experimental sequence-dependent effects with regard to initial CNO administration for the OLM task and the subsequent acquisition of ORM in the protocol used in this study. Specifically, there may be long-lasting network effects of CNO administration during OLM training that may affect the training in the ORM task. However, given that both hSyn-HM4D and CaMKII $\alpha-$ HM4D infused animals were able to acquire LTM for ORM after multiple administrations of CNO, this is unlikely. There were no detectable differences in motivation (exploration and total locomotion) during training sessions, and animals are able to acquire LTM for both OLM and ORM tasks. Thus, it is unlikely that $\mathrm{CNO}$ is affecting performance during the training sessions.

Most importantly in this study, we discovered promoterspecific effects of expressing DREADDs in the hippocampus on hippocampal LTP. The function of DREADDs on hippocampal LTP induced by TBS, a neuronal firing pattern occurring during exploratory behavior in rodents (Otto et al., 1991), had not been investigated previously. The hSyn-HM3D and hSyn-HM4D behavioral experiments led us to predict that hSyn-HM3D expression in the hippocampus would produce an enhancement in LTP, whereas an impairment in LTP was expected in slices from hSynHM4D-expressing mice. Surprisingly, we found the opposite. Application of CNO to slices expressing hSyn-HM3D in the dorsal hippocampus led to a significant decrease in amplitude of fEPSP and blocked TBS-induced LTP. In contrast, application of CNO to slices expressing hSyn-HM4D led to a significant increase in fEPSP amplitude and an enhancement of TBS-induced LTP. Our electrophysiological data suggest that CNO-induced depression of field responses in hSyn-HM3D mice may be driven by presynaptic activation of $\mathrm{GABA}_{\mathrm{A}}$ nerve terminals (Takahashi et al., 2007; Mathew and Hablitz, 2008), whereas hSyn-HM4Dmediated increase of fEPSP appears to be driven by depressing $\mathrm{GABA}_{\mathrm{A}}$-mediated currents. These results suggest that results obtained with hSyn promoter-driven DREADDs should be inter- preted carefully, particularly when used in adult ex vivo tissue with diverse local subpopulations.

CaMKII $\alpha$ has been shown to drive expression in excitatory glutamatergic forebrain neurons. As expected, application of CNO to hippocampal slices led to decreased amplitude of fEPSP in CaMKII $\alpha-H M 4 D$-expressing slices, while leading to significantly increased amplitude in CaMKII $\alpha-\mathrm{HM} 3 \mathrm{D}$-expressing slices. Moreover, CNO priming in CaMKII $\alpha-\mathrm{HM} 3 \mathrm{D}$-expressing slices led to enhanced TBS-induced LTP, whereas TBS-induced LTP was blocked in CaMKII $\alpha$-HM4D-expressing dorsal CA1 slices. These results matched the predicted outcome of the experiments as suggested by the expression pattern of CaMKII $\alpha$ and indicates that CaMKII $\alpha$ may be a more ideal promoter for DREADD manipulations in the hippocampus, especially for excitatory neuronal manipulation.

The contrast between electrophysiological and behavioral results via hSyn-mediated altered signaling remains poorly understood. The disparate results may be primarily attributable to nonspecific viral-infected cells within local interneuron population that are known to tightly regulate activity of CA1 pyramidal cells in this region (Sik et al., 1995; Klausberger, 2009; Haettig et al., 2013). hSyn viral expression in local interneurons would explain the increase in c-fos expression after $\mathrm{CNO}$ exposure in hSyn-HM4D infused mice (Fig. 1H). Interestingly, numerous reports have shown a dissociation between hippocampal LTP and hippocampus-dependent LTM using genetically modified mice (Nosten-Bertrand et al., 1996; Gerlai et al., 1998; Migaud et al., 1998; Brakebusch et al., 2002; Kaksonen et al., 2002; Vaillend et al., 2004; Nakauchi et al., 2015). Several of these studies focus on elements typically associated with modification to NMDA/ AMPA receptor function that produce an increase in stable LTP and a deficit in learning and memory tasks. Alternatively, Gerlai et al. (1998) proposed that an unregulated hyperexcitability induced by mutations to GluR2 led to enhanced LTP and impaired spatial learning. The commonality among several of these reports is that a subthreshold to threshold level of stimulation produced an increase in short-term potentiation followed by an enhancement of stable LTP relative to controls. The underlying mechanism responsible for a few of these mutant models was a decrease in inhibitory tone (Nosten-Bertrand et al., 1996; Vaillend et al., 2004). Consistent with these studies, we show that a subthreshold level of theta stimulation produced a marked increase in LTP in hSyn-HM4D infused mice relative to controls.

We also provide evidence that CNO infusions substantially reduced the amplitude of the fIPSP in hSyn-HM4D infused mice that was identical in time course and effect size after infusing the $\mathrm{GABA}_{\mathrm{A}}$ receptor antagonist PTX in control slices. These results strongly suggest that hSyn-HM4D virus interferes with inhibitory tone, which manifests as a notable increase in LTP and a decrease in learning and memory performance. In support of this conclusion, blocking $\mathrm{GABA}_{\mathrm{A}}$ receptors has been shown to enhance LTP by allowing greater postsynaptic depolarization and, thus, greater $\mathrm{Ca}^{2+}$ influx through NMDA receptors (Wigström and Gustafsson, 1983; Wigström and Gustafsson, 1985). Although at first glance, a reduction in stimulation threshold to raise the LTP ceiling for producing stable potentiation may seem an attractive approach to overcome disease-induced plasticity impairments associated with cognitive decline, neural network models of learning and memory that incorporate algorithms that can bidirectionally modify synapses predict that this type of animal model would ultimately cause saturation of synaptic function in a behaving animal and lead to negative consequences in processing information and its subsequent output to receiving 
cortical structures (Sejnowski, 1977; Bienenstock et al., 1982). Thus, animal models with similar phenotypes (enhanced LTP and impaired learning and memory) should be studied with caution. Although the goal of this study was not to determine the specific mechanism that interferes with the predicted outcome of hSyn-DREADD experiments, future studies may evaluate the particular interneuron population that leads to the counterintuitive effects on baseline synaptic signaling and hippocampal LTP.

Constructs implementing the hSyn promoter in other neuronal populations are likely to and already have been shown to yield the predicted effects on modulating cell activity (Chang et al., 2015; DiBenedictis et al., 2015; Gschwend et al., 2015; Huckstepp et al., 2015; Jovasevic et al., 2015; Pina et al., 2015; Robinson and Adelman, 2015; Sachs et al., 2015; Siegel et al., 2015; Ward et al., 2015; Koike et al., 2016). However, as DREADDs become more commonly used in regions with heterogeneous cell populations, it is critical to implement additional levels of specificity when using generic promoters, such as hSyn. In conjunction with transgenic animals expressing Cre under cell-type-specific promoters, Cre-dependent DREADDs (DIO-DREADD/FLEXDREADD) can be used to investigate directly the role particular cell types have in various neural circuits and behaviors. These FLEX constructs are inactive until exposed to Cre recombinase, which correctly orients the vector to allow full expression. (Stamatakis and Stuber, 2012; Andero et al., 2014; Boender et al., 2014; Cai et al., 2014; Cassataro et al., 2014; Mahler et al., 2014; Robinson et al., 2014). By limiting DREADD expression with particular promoters, future work can exclusively modulate neural activity at the cell-type-specific level.

In summary, there are many new exciting developments in the use of chemogenetics for exploring the function of specific cell types in specific circuits at relatively precise time periods. In this study, we found promoter-specific effects with regard to the hSyn promoter. The results demonstrated that, although the behavioral results obtained were as predicted, the underlying synaptic physiology was not. Thus, promoter-specific chemogenetic approaches should be used with multiple levels of analysis to interpret the ultimate behavioral effects as correctly as possible. With regard to hippocampal function, we further demonstrated that HM3D-mediated activation is capable of transforming a subthreshold learning event into a robust LTM. Finally, the results continue to add to the literature in rodents demonstrating that OLM is hippocampus dependent, whereas ORM is hippocampus independent.

\section{References}

Alexander GM, Rogan SC, Abbas AI, Armbruster BN, Pei Y, Allen JA, Nonneman RJ, Hartmann J, Moy SS, Nicolelis MA, McNamara JO, Roth BL (2009) Remote control of neuronal activity in transgenic mice expressing evolved G protein-coupled receptors. Neuron 63:27-39. CrossRef Medline

Alger BE, Nicoll RA (1982) Feed-forward dendritic inhibition in rat hippocampal pyramidal cells studied in vitro. J Physiol 328:105-123. CrossRef Medline

Andero R, Dias BG, Ressler KJ (2014) A role for Tac2, NkB, and Nk3 receptor in normal and dysregulated fear memory consolidation. Neuron 83: 444-454. CrossRef Medline

Arai A, Silberg J, Lynch G (1995) Differences in the refractory properties of two distinct inhibitory circuitries in field CA1 of the hippocampus. Brain Res 704:298-306. CrossRef Medline

Armbruster BN, Li X, Pausch MH, Herlitze S, Roth BL (2007) Evolving the lock to fit the key to create a family of $\mathrm{G}$ protein-coupled receptors potently activated by an inert ligand. Proc Natl Acad Sci U S A 104: 5163-5168. CrossRef Medline

Assini FL, Duzzioni M, Takahashi RN (2009) Object location memory in mice: pharmacological validation and further evidence of hippocampal CA1 participation. Behav Brain Res 204:206-211. CrossRef Medline

Bailey CP, Nicholls RE, Zhang XL, Zhou ZY, Müller W, Kandel ER, Stanton PK (2008) Galpha(i2) inhibition of adenylate cyclase regulates presynaptic activity and unmasks cGMP-dependent long-term depression at Schaffer collateral-CA1 hippocampal synapses. Learn Mem 15:261-270. CrossRef Medline

Balderas I, Rodriguez-Ortiz CJ, Salgado-Tonda P, Chavez-Hurtado J, McGaugh JL, Bermudez-Rattoni F (2008) The consolidation of object and context recognition memory involve different regions of the temporal lobe. Learn Mem 15:618-624. CrossRef Medline

Barrett RM, Malvaez M, Kramar E, Matheos DP, Arrizon A, Cabrera SM, Lynch G, Greene RW, Wood MA (2011) Hippocampal focal knockout of CBP affects specific histone modifications, long-term potentiation, and long-term memory. Neuropsychopharmacology 36:1545-1556. CrossRef Medline

Bermudez-Rattoni F, Okuda S, Roozendaal B, McGaugh JL (2005) Insular cortex is involved in consolidation of object recognition memory. Learn Mem 12:447-449. CrossRef Medline

Berridge MJ, Bootman MD, Lipp P (1998) Calcium—a life and death signal. Nature 395:645-648. CrossRef Medline

Bienenstock EL, Cooper LN, Munro PW (1982) Theory for the development of neuron selectivity: orientation specificity and binocular interaction in visual cortex. J Neurosci 2:32-48. Medline

Boender AJ, de Jong JW, Boekhoudt L, Luijendijk MC, van der Plasse G, Adan RA (2014) Combined use of the canine adenovirus-2 and DREADDtechnology to activate specific neural pathways in vivo. PLoS One 9:e95392. CrossRef Medline

Brakebusch C, Seidenbecher CI, Rauch U, Matthies H, Meyer H, Krug M, Böckers TM, Zhou X, Kreutz R, Montag D, Gundelfinger ED, Asztely F, Bo TM, Kreutz MR, Fässler R (2002) Brevican-deficient mice display impaired hippocampal CA1 long-term potentiation but show no obvious deficits in learning and memory brevican-deficient mice display impaired hippocampal CA1 long-term potentiation but show no obvious deficits in learning and memory. Mol Cell Biol 22:7417-7427. Medline

Cai H, Haubensak W, Anthony TE, Anderson DJ (2014) Central amygdala PKC- $\delta+$ neurons mediate the influence of multiple anorexigenic signals. Nat Neurosci 17:1240-1248. CrossRef Medline

Cassataro D, Bergfeldt D, Malekian C, Van Snellenberg JX, Thanos PK, Fishell G, Sjulson L (2014) Reverse pharmacogenetic modulation of the nucleus accumbens reduces ethanol consumption in a limited access paradigm. Neuropsychopharmacology 39:283-290. CrossRef Medline

Chang SE, Todd TP, Bucci DJ, Smith KS (2015) Chemogenetic manipulation of ventral pallidal neurons impairs acquisition of sign-tracking in rats. Eur J Neurosci 42:3105-3116. CrossRef Medline

Chapman CA, Perez Y, Lacaille JC (1998) Effects of GABA(A) inhibition on the expression of long-term potentiation in CA1 pyramidal cells are dependent on tetanization parameters. Hippocampus 8:289-298. CrossRef Medline

DeBock F, Kurz J, Azad SC, Parsons CG, Hapfelmeier G, Zieglgänsberger W, Rammes G (2003) alpha2-Adrenoreceptor activation inhibits LTP and LTD in the basolateral amygdala: involvement of Gi/o-protein-mediated modulation of $\mathrm{Ca} 2+$-channels and inwardly rectifying $\mathrm{K}+$-channels in LTD. Eur J Neurosci 17:1411-1424. CrossRef Medline

Dere E, Huston JP, De Souza Silva MA (2007) The pharmacology, neuroanatomy and neurogenetics of one-trial object recognition in rodents. Neurosci Biobehav Rev 31:673-704. CrossRef Medline

DiBenedictis BT, Olugbemi AO, Baum MJ, Cherry JA (2015) DREADDinduced silencing of the medial olfactory tubercle disrupts the preference of female mice for opposite-sex chemosignals. eNeuro 2:pii: ENEURO.0078-15.2015. CrossRef Medline

Dittgen T, Nimmerjahn A, Komai S, Licznerski P, Waters J, Margrie TW, Helmchen F, Denk W, Brecht M, Osten P (2004) Lentivirus-based genetic manipulations of cortical neurons and their optical and electrophysiological monitoring in vivo. Proc Natl Acad Sci U S A 101:18206-18211. CrossRef Medline

Dong S, Allen JA, Farrell M, Roth BL (2010a) A chemical-genetic approach for precise spatio-temporal control of cellular signaling. Mol Biosyst 6:1376-1380. CrossRef Medline

Dong S, Rogan SC, Roth BL (2010b) Directed molecular evolution of DREADDs: a generic approach to creating next-generation RASSLs. Nat Protoc 5:561-573. CrossRef Medline 
Ennaceur A (2010) One-trial object recognition in rats and mice: Methodological and theoretical issues. Behav Brain Res 215:244-254. CrossRef Medline

Ferguson SM, Neumaier JF (2014) Using DREADDs to investigate addiction behaviors. Curr Opin Behav Sci 2:69-72. CrossRef

Ferguson SM, Eskenazi D, Ishikawa M, Wanat MJ, Phillips PE, Dong Y, Roth BL, Neumaier JF (2011) Transient neuronal inhibition reveals opposing roles of indirect and direct pathways in sensitization. Nat Neurosci 14: 22-24. CrossRef Medline

Fortress AM, Hamlett ED, Vazey EM, Aston-Jones G, Cass WA, Boger HA, Granholm AC (2015) Designer receptors enhance memory in a mouse model of Down syndrome. J Neurosci 35:1343-1353. CrossRef Medline

Garner AR, Rowland DC, Hwang SY, Baumgaertel K, Roth BL, Kentros C, Mayford M (2012) Generation of a synthetic memory trace. Science 335: 1513-1516. CrossRef Medline

Gerlai R, Henderson JT, Roder JC, Jia Z (1998) Multiple behavioral anomalies in GluR2 mutant mice exhibiting enhanced LTP. Behav Brain Res 95:37-45. CrossRef Medline

Greget R, Pernot F, Bouteiller JM, Ghaderi V, Allam S, Keller AF, Ambert N, Legendre A, Sarmis M, Haeberle O, Faupel M, Bischoff S, Berger TW, Baudry M (2011) Simulation of postsynaptic glutamate receptors reveals critical features of glutamatergic transmission. PLoS One 6:e28380 CrossRef Medline

Grover LM, Yan C (1999) Blockade of GABAA receptors facilitates induction of NMDA receptor-independent long-term potentiation. J Neurophysiol 81:2814-2822. Medline

Gschwend O, Abraham NM, Lagier S, Begnaud F, Rodriguez I, Carleton A (2015) Neuronal pattern separation in the olfactory bulb improves odor discrimination learning. Nat Neurosci 18:1474-1482. CrossRef Medline

Haettig J, Stefanko DP, Multani ML, Figueroa DX, McQuown SC, Wood MA (2011) HDAC inhibition modulates hippocampus-dependent longterm memory for object location in a CBP-dependent manner. Learn Mem 18:71-79. CrossRef Medline

Haettig J, Sun Y, Wood MA, Xu X (2013) Cell-type specific inactivation of hippocampal CA1 disrupts location-dependent object recognition in the mouse. Learn Mem 20:139-146. CrossRef Medline

Huckstepp RT, Cardoza KP, Henderson LE, Feldman JL (2015) Role of parafacial nuclei in control of breathing in adult rats. J Neurosci 35:10521067. CrossRef Medline

Ishii K, Kubo K, Endo T, Yoshida K, Benner S, Ito Y, Aizawa H, Aramaki M, Yamanaka A, Tanaka K, Takata N, Tanaka KF, Mimura M, Tohyama C, Kakeyama M, Nakajima K (2015) Neuronal heterotopias affect the activities of distant brain areas and lead to behavioral deficits. J Neurosci 35:12432-12445. CrossRef Medline

Jovasevic V, Corcoran KA, Leaderbrand K, Yamawaki N, Guedea AL, Chen HJ, Shepherd GM, Radulovic J (2015) GABAergic mechanisms regulated by miR-33 encode state-dependent fear. Nat Neurosci 18:12651271. CrossRef Medline

Kaksonen M, Pavlov I, Võikar V, Lauri SE, Hienola A, Riekki R, Lakso M, Taira T, Rauvala H (2002) Syndecan-3-deficient mice exhibit enhanced LTP and impaired hippocampus-dependent memory. Mol Cell Neurosci 21:158-172. CrossRef Medline

Klausberger T (2009) GABAergic interneurons targeting dendrites of pyramidal cells in the CA1 area of the hippocampus. Eur J Neurosci 30: 947-957. CrossRef Medline

Koike H, Demars MP, Short JA, Nabel EM, Akbarian S, Baxter MG, Morishita H (2016) Chemogenetic inactivation of dorsal anterior cingulate cortex neurons disrupts attentional behavior in mouse. Neuropsychopharmacology 41:1014-1023. CrossRef Medline

Kügler S, Kilic E, Bähr M (2003) Human synapsin 1 gene promoter confers highly neuron-specific long-term transgene expression from an adenoviral vector in the adult rat brain depending on the transduced area. Gene Ther 10:337-347. Medline

Lambert NA, Borroni AM, Grover LM, Teyler TJ (1991) Hyperpolarizing and depolarizing GABAA receptor-mediated dendritic inhibition in area CA1 of the rat hippocampus. J Neurophysiol 66:1538-1548. Medline

Lee HM, Giguere PM, Roth BL (2014) DREADDs: novel tools for drug discovery and development. Drug Discov Today 19:469-473. CrossRef Medline

Mahler SV, Vazey EM, Beckley JT, Keistler CR, McGlinchey EM, Kaufling J, Wilson SP, Deisseroth K, Woodward JJ, Aston-Jones G (2014) Designer receptors show role for ventral pallidum input to ventral tegmental area in cocaine seeking. Nat Neurosci 17:577-585. CrossRef Medline

Mathew SS, Hablitz JJ (2008) Calcium release via activation of presynaptic IP3 receptors contributes to kainate-induced IPSC facilitation in rat neocortex. Neuropharmacology 55:106-116. CrossRef Medline

Mayford M, Bach ME, Huang YY, Wang L, Hawkins RD, Kandel ER (1996) Control of memory formation through regulated expression of a CaMKII transgene. Science 274:1678-1683. CrossRef Medline

McQuown SC, Barrett RM, Matheos DP, Post RJ, Rogge GA, Alenghat T, Mullican SE, Jones S, Rusche JR, Lazar MA, Wood MA (2011) HDAC3 is a critical negative regulator of long-term memory formation. J Neurosci 31:764-774. CrossRef Medline

Migaud M, Charlesworth P, Dempster M, Webster LC, Watabe AM, Makhinson M, He Y, Ramsay MF, Morris RG, Morrison JH, O’Dell TJ, Grant SG (1998) Enhanced long-term potentiation and impaired learning in mice with mutant postsynaptic density-95 protein. Nature 396:433-439. CrossRef Medline

Mumby DG (2001) Perspectives on object-recognition memory following hippocampal damage: lessons from studies in rats. Behav Brain Res 127: 159-181. CrossRef Medline

Mumby DG, Gaskin S, Glenn MJ, Schramek TE, Lehmann H (2002) Hippocampal damage and exploratory preferences in rats: memory for objects, places, and contexts. Learn Mem 9:49-57. Medline

Nair SG, Strand NS, Neumaier JF (2013) DREADDing the lateral habenula: a review of methodological approaches for studying lateral habenula function. Brain Res 1511:93-101. CrossRef Medline

Nakauchi S, Malvaez M, Su H, Kleeman E, Dang R, Wood MA, Sumikawa K (2015) Early postnatal nicotine exposure causes hippocampusdependent memory impairments in adolescent mice: association with altered nicotinic cholinergic modulation of LTP, but not impaired LTP. Neurobiol Learn Mem 118:178-188. CrossRef Medline

Nosten-Bertrand M, Errington ML, Murphy KP, Tokugawa Y, Barboni E, Kozlova E, Michalovich D, Morris RG, Silver J, Stewart CL, Bliss TV, Morris RJ (1996) Normal spatial learning despite regional inhibition of LTP in mice lacking Thy-1. Nature 379:826-829. CrossRef Medline

Otto T, Eichenbaum H, Wiener SI, Wible CG (1991) Learning-related patterns of CA1 spike trains parallel stimulation parameters optimal for inducing hippocampal long-term potentiation. Hippocampus 1: 181-192. CrossRef Medline

Pfaffl MW (2001) A new mathematical model for relative quantification in real-time RT-PCR. Nucleic Acids Res 29:e45. Medline

Pfaffl MW, Georgieva TM, Georgiev IP, Ontsouka E, Hageleit M, Blum JW (2002) Real-time RT-PCR quantification of insulin-like growth factor (IGF)-1, IGF-1 receptor, IGF-2, IGF-2 receptor, insulin receptor, growth hormone receptor, IGF-binding proteins 1,2 and 3 in the bovine species. Domest Anim Endocrinol 22:91-102. CrossRef Medline

Pina MM, Young EA, Ryabinin AE, Cunningham CL (2015) The bed nucleus of the stria terminalis regulates ethanol-seeking behavior in mice. Neuropharmacology 99:627-638. CrossRef Medline

Pradhan A, Liu Y (2004) The calcium-responsive transactivator recruits CREB binding protein to nuclear bodies. Neurosci Lett 370:191-195. Medline

Robinson S, Adelman JS (2015) A method for remotely silencing neural activity in rodents during discrete phases of learning. J Vis Exp (100): e52859. CrossRef

Robinson S, Todd TP, Pasternak AR, Luikart BW, Skelton PD, Urban DJ, Bucci DJ (2014) Chemogenetic silencing of neurons in retrosplenial cortex disrupts sensory preconditioning. J Neurosci 34:10982-10988. CrossRef Medline

Rogan SC, Roth BL (2011) Remote control of neuronal signaling. Pharmacol Rev 63:291-315. CrossRef Medline

Rogge GA, Singh H, Dang R, Wood MA (2013) HDAC3 is a negative regulator of cocaine-context-associated memory formation. J Neurosci 33: 6623-6632. CrossRef Medline

Roggenhofer E, Fidzinski P, Shor O, Behr J (2013) Reduced threshold for induction of LTP by activation of dopamine D1/D5 receptors at hippocampal CA1-subiculum synapses. PLoS One 8:e62520. CrossRef Medline

Rossato JI, Bevilaqua LR, Myskiw JC, Medina JH, Izquierdo I, Cammarota M (2007) On the role of hippocampal protein synthesis in the consolidation and reconsolidation of object recognition memory. Learn Mem 14: 36-46. Medline 
Sachs BD, Ni JR, Caron MG (2015) Brain 5-HT deficiency increases stress vulnerability and impairs antidepressant responses following psychosocial stress. Proc Natl Acad Sci U S A 112:2557-2562. CrossRef Medline

Sano Y, Shobe JL, Zhou M, Huang S, Shuman T, Cai DJ, Golshani P, Kamata M, Silva AJ (2014) CREB regulates memory allocation in the insular cortex. Curr Biol 24:2833-2837. CrossRef Medline

Scheyltjens I, Laramée ME, Van den Haute C, Gijsbers R, Debyser Z, Baekelandt V, Vreysen S, Arckens L (2015) Evaluation of the expression pattern of rAAV2/1,2/5, 2/7, 2/8, and 2/9 serotypes with different promoters in the mouse visual cortex. J Comp Neurol 523:2019-2042. CrossRef Medline

Sejnowski TJ (1977) Statistical constraints on synaptic plasticity. J Theor Biol 69:385-389. Medline

Siegel CS, Fink KL, Strittmatter SM, Cafferty WB (2015) Plasticity of intact rubral projections mediates spontaneous recovery of function after corticospinal tract injury. J Neurosci 35:1443-1457. CrossRef Medline

Sik A, Penttonen M, Ylinen A, Buzsáki G (1995) Hippocampal CA1 interneurons: an in vivo intracellular labeling study. J Neurosci 15:66516665. Medline

Stamatakis AM, Stuber GD (2012) Activation of lateral habenula inputs to the ventral midbrain promotes behavioral avoidance. Nat Neurosci 15: 1105-1107. CrossRef Medline

Stefanko DP, Barrett RM, Ly AR, Reolon GK, Wood MA (2009) Modulation of long-term memory for object recognition via HDAC inhibition. Proc Natl Acad Sci U S A 106:9447-9452. CrossRef Medline

Suárez LM, Bustamante J, Orensanz LM, Martín del Río R, Solís JM (2014) Cooperation of taurine uptake and dopamine D1 receptor activation facilitates the induction of protein synthesis-dependent late LTP. Neuropharmacology 79:101-111. CrossRef Medline

Takahashi A, Mikami M, Yang J (2007) Hydrogen peroxide increases GABAergic mIPSC through presynaptic release of calcium from IP3 receptor-sensitive stores in spinal cord substantia gelatinosa neurons. Eur J Neurosci 25:705-716. Medline

Tsuda MC, Yeung HM, Kuo J, Usdin TB (2015) Incubation of fear is regulated by TIP39 peptide signaling in the medial nucleus of the amygdala. J Neurosci 35:12152-12161. CrossRef Medline

Vaillend C, Billard JM, Laroche S (2004) Impaired long-term spatial and recognition memory and enhanced CA1 hippocampal LTP in the dystrophin-deficient Dmdmdx mouse. Neurobiol Dis 17:10-20. CrossRef Medline

Vogel-Ciernia A, Matheos DP, Barrett RM, Kramár EA, Azzawi S, Chen Y, Magnan CN, Zeller M, Sylvain A, Haettig J, Jia Y, Tran A, Dang R, Post RJ, Chabrier M, Babayan AH, Wu JI, Crabtree GR, Baldi P, Baram TZ, Lynch G, Wood MA (2013) The neuron-specific chromatin regulatory subunit BAF53b is necessary for synaptic plasticity and memory. Nat Neurosci 16:552-561. CrossRef Medline
Vogel-Ciernia A, Wood MA (2014) Examining object location and object recognition memory in mice. Curr Protoc Neurosci 69:8.31.1-8.31.17. CrossRef Medline

Ward RD, Winiger V, Kandel ER, Balsam PD, Simpson EH (2015) Orbitofrontal cortex mediates the differential impact of signaled-reward probability on discrimination accuracy. Front Neurosci 9:230. CrossRef Medline

White MD, Milne RV, Nolan MF (2011) A molecular toolbox for rapid generation of viral vectors to up- or down-regulate neuronal gene expression in vivo. Front Mol Neurosci 4:8. CrossRef Medline

Wigström H, Gustafsson B (1983) Heterosynaptic modulation of homosynaptic long-lasting potentiation in the hippocampal slice. Acta Physiol Scand 119:455-458. Medline

Wigström H, Gustafsson B (1985) Facilitation of hippocampal long-lasting potentiation by GABA antagonists. Acta Physiol Scand 125:159-172. Medline

Winters BD, Bussey TJ (2005) Transient inactivation of perirhinal cortex disrupts encoding, retrieval, and consolidation of object recognition memory. J Neurosci 25:52-61. CrossRef Medline

Winters BD, Forwood SE, Cowell RA, Saksida LM, Bussey TJ (2004) Double dissociation between the effects of peri-postrhinal cortex and hippocampal lesions on tests of object recognition and spatial memory: heterogeneity of function within the temporal lobe. J Neurosci 24:5901-5908. CrossRef Medline

Winters BD, Saksida LM, Bussey TJ (2008) Object recognition memory: neurobiological mechanisms of encoding, consolidation and retrieval. Neurosci Biobehav Rev 32:1055-1070. CrossRef Medline

Wong ST, Athos J, Figueroa XA, Pineda VV, Schaefer ML, Chavkin CC, Muglia LJ, Storm DR (1999) Calcium-stimulated adenylyl cyclase activity is critical for hippocampus-dependent long-term memory and late phase LTP. Neuron 23:787-798. CrossRef Medline

Wu ZL, Thomas SA, Villacres EC, Xia Z, Simmons ML, Chavkin C, Palmiter RD, Storm DR (1995) Altered behavior and long-term potentiation in type I adenylyl cyclase mutant mice. Proc Natl Acad Sci U S A 92:220-224. CrossRef Medline

Xia Z, Storm DR (1997) Adenylyl cyclases and neuromodulation. Convergence 7:391-396.

Yau JO, McNally GP (2015) Pharmacogenetic excitation of dorsomedial prefrontal cortex restores fear prediction error. J Neurosci 35:74-83. CrossRef Medline

Zhu H, Roth BL (2014) Silencing synapses with DREADDs. Neuron 82: 723-725. CrossRef Medline

Zhu H, Pleil KE, Urban DJ, Moy SS, Kash TL, Roth BL (2014) Chemogenetic inactivation of ventral hippocampal glutamatergic neurons disrupts consolidation of contextual fear memory. Neuropsychopharmacology 39 : 1880-1892. CrossRef Medline 